\title{
Genetically encoded optical sensors for monitoring of intracellular chloride and chloride-selective channel activity
}

\section{Piotr Bregestovski *, Tatyana Waseem ${ }^{\dagger}$ and Marat Mukhtarov}

Mediterranean Institute of Neurobiology, INSERM U901, Marseille, France

\section{Edited by:}

Jochen C. Meier, Max Delbrück Center for Molecular Medicine, Germany

\section{Reviewed by:}

Joe Lynch, University of Queensland, Australia

Jochen C. Meier, Max Delbrück Center for Molecular Medicine, Germany

\section{${ }^{*}$ Correspondence:}

Piotr Bregestovski, Institut de Neurobiologie de la Méditerranée, INSERM U901, Parc Scientifique de Luminy, 13273 Marseille, France. e-mail:pbreges@inmed.univ-mrs.fr

${ }^{\dagger}$ Permanent address: Tatyana Waseem, Institute of Biophysics and Cell Engineering, National Academy of Sciences, Minsk, Belarus
This review briefly discusses the main approaches for monitoring chloride $\left(\mathrm{Cl}^{-}\right)$, the most abundant physiological anion. Noninvasive monitoring of intracellular $\mathrm{Cl}^{-}\left(\left[\mathrm{Cl}^{-}\right]\right.$;) is a challenging task owing to two main difficulties: (i) the low transmembrane ratio for $\mathrm{Cl}^{-}$, approximately 10:1; and (ii) the small driving force for $\mathrm{Cl}^{-}$, as the $\mathrm{Cl}^{-}$reversal potential $\left(E_{C)}\right)$ is usually close to the resting potential of the cells. Thus, for reliable monitoring of intracellular $\mathrm{Cl}^{-}$, one has to use highly sensitive probes. From several methods for intracellular $\mathrm{Cl}^{-}$analysis, genetically encoded chloride indicators represent the most promising tools. Recent achievements in the development of genetically encoded chloride probes are based on the fact that yellow fluorescent protein (YFP) exhibits $\mathrm{Cl}^{-}$-sensitivity. YFP-based probes have been successfully used for quantitative analysis of $\mathrm{Cl}^{-}$transport in different cells and for high-throughput screening of modulators of $\mathrm{Cl}^{-}$-selective channels. Development of a ratiometric genetically encoded probe, Clomeleon, has provided a tool for noninvasive estimation of intracellular $\mathrm{Cl}^{-}$concentrations. While the sensitivity of this protein to $\mathrm{Cl}^{-}$is low ( $\mathrm{EC}_{50}$ about $160 \mathrm{mM}$ ), it has been successfully used for monitoring intracellular $\mathrm{Cl}^{-}$in different cell types. Recently a CFP-YFP-based probe with a relatively high sensitivity to $\mathrm{Cl}^{-}$ $\left(E_{50}\right.$ about $30 \mathrm{mM}$ ) has been developed. This construct, termed Cl-Sensor, allows ratiometric monitoring using the fluorescence excitation ratio. Of particular interest are genetically encoded probes for monitoring of ion channel distribution and activity. A new molecular probe has been constructed by introducing into the cytoplasmic domain of the $\mathrm{Cl}^{-}$-selective glycine receptor (GlyR) channel the CFP-YFP-based Cl-Sensor. This construct, termed BioSensor-GlyR, has been successfully expressed in cell lines. The new genetically encoded chloride probes offer means of screening pharmacological agents, analysis of $\mathrm{Cl}^{-}$homeostasis and functions of $\mathrm{Cl}^{-}$-selective channels under different physiological and pathological conditions.

Keywords: fluorescent proteins, noninvasive monitoring, ion-sensitive microelectrodes, fluorescent dyes, quinolinium indicators, glycine receptor channel, FRET

\section{INTRODUCTION}

Fluorescent indicators designed for quantitative monitoring of intracellular ions and analysis of the distribution of various proteins have brought about a revolution in obtaining important information about the functioning, development and pathology of cells and cellular components of biological organisms.

In this review we will briefly discuss the main approaches for monitoring chloride $\left(\mathrm{Cl}^{-}\right)$, the most abundant physiological anion. $\mathrm{Cl}^{-}$is present in every cell of biological organisms and participates in a variety of important cellular processes, such as neurotransmission, regulation of cell volume, $\mathrm{pH}$ and water-salt balance. The concentration of intracellular $\mathrm{Cl}^{-}$and its permeance is highly regulated by a variety of $\mathrm{Cl}^{-}$-selective channels and $\mathrm{Cl}^{-}$transporters

Abbreviations: CFP, cyan fluorescent protein; CFTR, cystic fibrosis transmembrane conductance regulator (protein); $\mathrm{CHO}$, chinese hamster ovary (cells); $\mathrm{CMV}$, cytomegalovirus (promoter); FRET, fluorescence resonance energy transfer; GABA, $\gamma$-aminobutyric acid; GFP, green fluorescent protein; GlyR, glycine receptor; HEK, human embryonic kidney (cells); HTP, high-throughput (screening); YFP, yellow fluorescent protein; MEQ, 6-methoxy-N-ethylquinolium; MQAE, N-(6-methoxyquinolyl)-acetoethyl ester; SPQ, 6-methoxy-N-(3-sulfopropyl) quinolinium; TFP, topaz fluorescent protein; VCF, voltage-clamp fluorometry; WT, wild type; YFP, yellow fluorescent protein. (revs. Chen and Hwang, 2008; Jentsch, 2008). Dysfunction of these proteins results in a various diseases. For instance, the most prevalent lethal genetic disease, cystic fibrosis (Kerem et al., 1989), arises from mutations in the specific regulator of $\mathrm{Cl}^{-}$permeability, cystic fibrosis transmembrane conductance regulator (CFTR) protein. This voltage-independent $\mathrm{Cl}^{-}$channel is found in the epithelial cells of many tissues (intestine, lung, reproductive tract, pancreatic ducts). Mutations in the gene encoding CFTR affect 1 in 2000-2500 people (Ashcroft, 2000). Several other human diseases have been linked to dysfunction of $\mathrm{Cl}^{-}$channels or transporters: myotonia congenita (Koch et al., 1992), congenital chloride diarrhoea (Kere et al., 1999), inherited hypercalciuric nephrolithiasis (Lloyd et al., 1996), Bartter's and Gitelman's syndromes (Simon and Lifton, 1996), hyperekplexia/startle disease (Shiang et al., 1993) and epilepsy (Macdonald et al., 2004; Lerche et al., 2005; Heron et al., 2007; Dibbens et al., 2009).

Direct measurement of intracellular $\mathrm{Cl}^{-}$concentration $\left(\left[\mathrm{Cl}^{-}\right]_{\mathrm{i}}\right)$ in neurons and in other cell types is a challenging task owing to two main difficulties: (i) low transmembrane ratio for $\mathrm{Cl}^{-}$, approximately 10:1 (for Ca, for instance, 10000:1); and (ii) a small driving force for $\mathrm{Cl}^{-}$, as the $\mathrm{Cl}^{-}$reversal potential $\left(E_{\mathrm{Cl}}\right)$ is usually close to the 
resting potential of the cells. Consequently, sensitive probes with high dynamic range at physiological $\left[\mathrm{Cl}^{-}\right]_{\mathrm{i}}$ are necessary for reliable analysis of $\left[\mathrm{Cl}^{-}\right]_{\mathrm{i}}$ distribution and its functional variations.

For $\left[\mathrm{Cl}^{-}\right]_{\mathrm{i}}$ monitoring several methods have been proposed. The most used are $\mathrm{Cl}^{-}$-selective microelectrodes; chloride-sensitive fluorescent dyes and genetically encoded chloride-sensitive probes. We will briefly describe these approaches with the main focus on genetically encoded chloride-sensitive probes, which are the most promising tools for effective analysis of $\mathrm{Cl}^{-}$homeostasis in various cell types.

\section{Cl' SELECTIVE MICROELECTRODES}

In the 1960s, 70s and 80s the use of ion-selective electrodes was the main available technique for intracellular $\mathrm{Cl}^{-}$detection. It allowed valuable information on $\mathrm{Cl}^{-}$distribution and dynamics in a number of cell types of biological organisms to be obtained. In very early studies, $\mathrm{AgCl}$ electrodes were used as tools for $\left[\mathrm{Cl}^{-}\right]_{\mathrm{i}}$ estimation (Mauro, 1954; Keynes, 1963; Strickholm and Wallin, 1965; Sato et al., 1968). With an electrode consisting of a fine $\mathrm{AgCl}$ wire protruding from the end of a glass capillary, $\left[\mathrm{Cl}^{-}\right]_{\mathrm{i}}$ was measured in giant axons of squid (Mauro, 1954; Keynes, 1963) and crayfish (Strickholm and Wallin, 1965). However, later observations demonstrated that all microelectrodes that use $\mathrm{AgCl}$ as the sensitive element develop "the same type of error in the intracellular environment and thus all give erroneously high values of $\left[\mathrm{Cl}^{-}\right]_{i}$ " (Neild and Thomas, 1974).

The improved method was based on the use of siliconized borosilicate glass micropipettes, the tips of which were filled with liquid chloride ion exchanger. This technique was introduced by Walker (1971) and used with some modifications in a number of studies (Walker and Brown, 1970; Neild and Thomas, 1974; Ascher et al., 1976; Vaughan-Jones, 1979). These electrodes (Figure 1A) had a small tip (1-2 $\mu \mathrm{m})$ and gave complete responses to changes in $\mathrm{Cl}^{-}$ within 1-2 min. Preparing these electrodes is a time-consuming procedure and penetration of cells without damage is difficult.

Despite these complications, $\mathrm{Cl}^{-}$-sensitive microelectrodes were successfully used to measure the intracellular $\mathrm{Cl}^{-}$activity in giant neurons of molluscs Aplysia (Brown et al., 1970; Ascher et al., 1976) and Helix aspersa (Neild and Thomas, 1974; Kennedy and Thomas, 1995; Schwiening and Thomas, 1996), in frog heart cells (Ladle and Walker, 1975; Vaughan-Jones, 1979) and in other preparations (Walker and Brown, 1977; Thomas, 1978).

An intracellular $\mathrm{Cl}^{-}$-sensitive microelectrode records the algebraic sum of the membrane potential $\left(E_{\mathrm{m}}\right)$ and a voltage proportional to changes in $\mathrm{Cl}^{-}$activity. It means that $E_{\mathrm{m}}$ must be separately determined using an independent electrode (Figure 1B). To diminish the damage from insertion of two microelectrodes into a single cell, double-barrelled pipettes were proposed (Aickin, 1981) and used for monitoring the intracellular $\mathrm{Cl}^{-}$activity in smooth muscle cells (Aickin and Brading, 1982; Davis et al., 2000), retinal pigment epithelium (Bialek et al., 1995; La Cour et al., 1997) and in other cell types (Kitano et al., 1995; Debellis et al., 2001; Ianowski et al., 2002).

Early studies with $\mathrm{Cl}^{-}$-sensitive microelectrodes already demonstrated that $\left[\mathrm{Cl}^{-}\right]_{\mathrm{i}}$ in cells differs substantially from a predicted passive distribution, suggesting that $\mathrm{Cl}^{-}$ions must be actively transported through cellular membranes. These observations were confirmed by the more recent discovery of several mechanisms of transmembrane $\mathrm{Cl}^{-}$transport (rev. Russell, 2000; Lauf and Adragna, 2004).

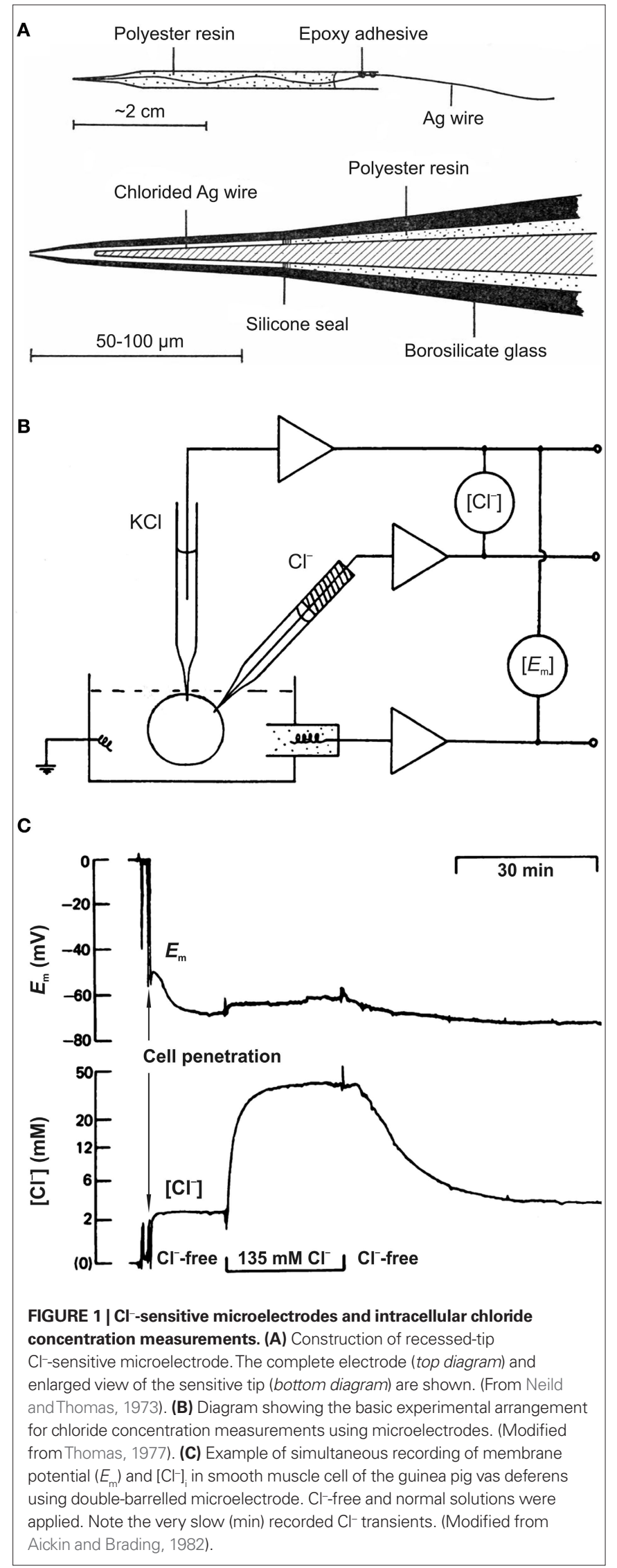


Three main obstacles limited the spread of the $\mathrm{Cl}^{-}$-sensitive microelectrode technique: (i) time-consuming procedure for microelectrode preparation; (ii) slow kinetics (Figure 1C); and (iii) the need to use relatively large cells for reliable recording without cell damage. In addition, penetration of cells could change the native intracellular $\mathrm{Cl}^{-}$distribution. Methods based on imaging techniques are more promising as they provide an opportunity to monitor $\mathrm{Cl}^{-}$activity noninvasively and in populations of cells.

\section{FLUORESCENT CI' SENSITIVE DYES}

Because of the possibility of monitoring noninvasively the distribution and dynamics of ion concentration changes, fluorescent $\mathrm{Cl}^{-}$sensitive dyes are the most popular approach for analysis of $\mathrm{Cl}^{-}$and $\mathrm{Cl}^{-}$-dependent physiological processes in different cells types.
The fluorescence of many fluorophores is decreased on application of heavy-atom anions, such as bromine and iodine. $\mathrm{Cl}^{-}$ions are less effective in this respect and relatively few fluorophores are quenched by $\mathrm{Cl}^{-}$(Geddes et al., 2001). The background for $\mathrm{Cl}^{-}$monitoring was established by George Stokes, who described in 1852 the phenomenon of fluorescence. In 1869 Stokes observed that the "fluorescence of quinine in dilute sulfuric acid was reduced after the addition of hydrochloric acid, i.e., chloride ions" (Geddes et al., 2001). Perhaps the fact that quinine, which is sensitive to chloride, contains a quinoline ring has stimulated the production of many quinoline analogues in the search for efficient $\mathrm{Cl}^{-}$probes.

Quinolinium $\mathrm{Cl}^{-}$indicators are based on the capability of halides to quench the fluorescence of heterocyclic organic compounds with quaternary nitrogen (Chen et al., 1988; Verkman, 1990; Figure 2A).

\section{A}<smiles>[R]c1ccc2c(ccc[n+]2[R2])c1</smiles><smiles>CCOC(=O)C[n+]1cccc2cc(OC)ccc21</smiles>

B
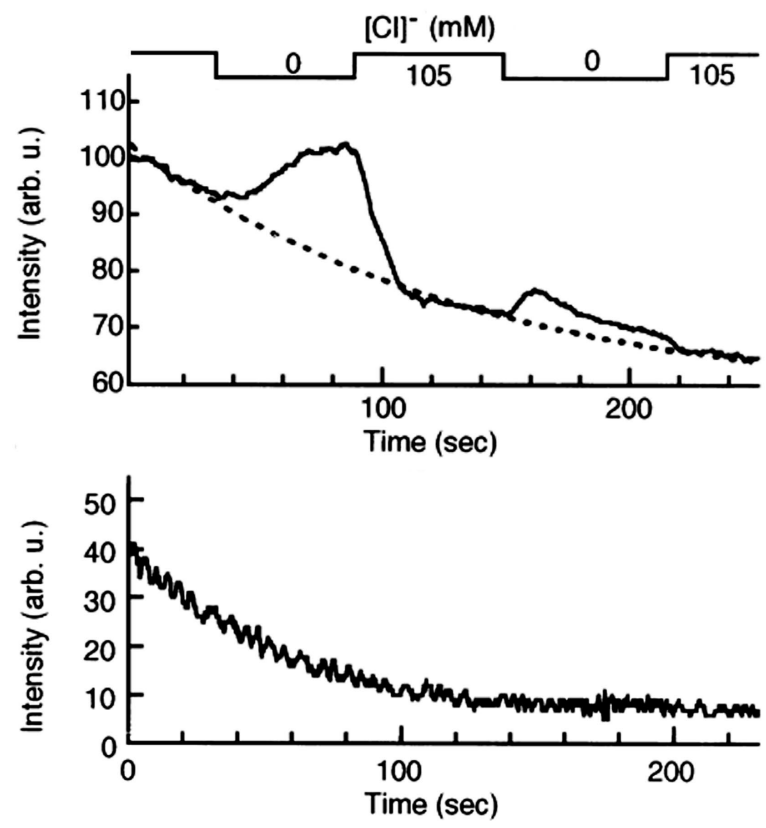

FIGURE 2 | Chemical structure and fluorescent properties of widely used $\mathrm{Cl}^{-}$-sensitive dyes. (A) Chemical structure of quinolinium $\mathrm{Cl}^{-}$-sensitive dyes. Left: Common structure, $\mathrm{R}_{1}$ and $\mathrm{R}_{2^{\prime}}$ radicals. Middle and right. Structural formula for $\mathrm{SPQ}$ and MQAE dyes respectively. (B) Examples of continuous fluorescence measurements of the MQAE-loaded cells. Note the rapid degradation in baseline fluorescence value (top and bottom traces) and dramatic
C
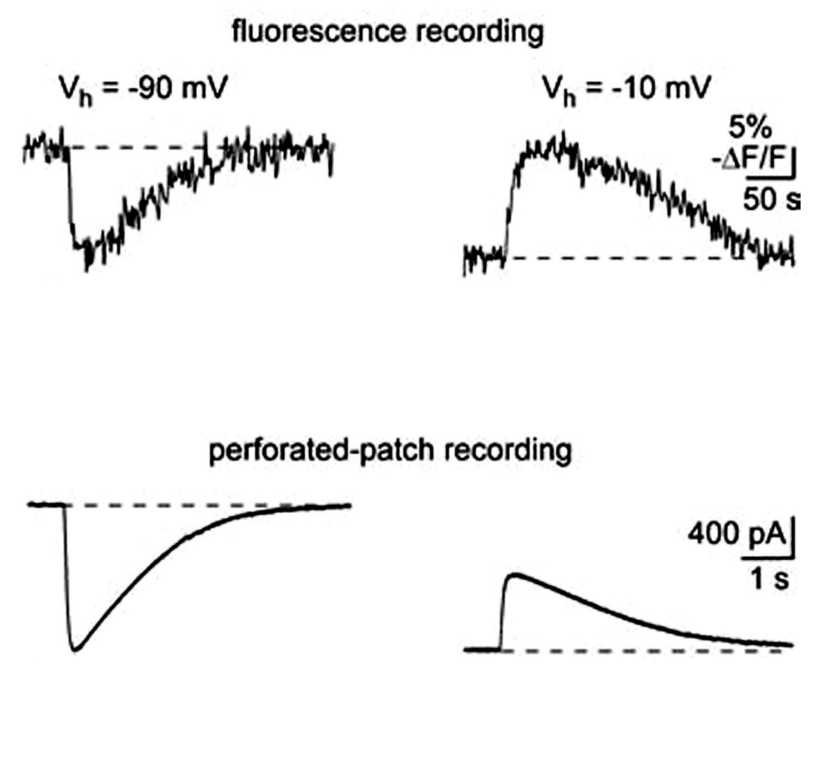

decrease in the fluorescent response for the second transition from 105 to $0 \mathrm{mM}$ of $\mathrm{Cl}^{-}$(top trace). (Modified from Nakamura et al., 1997). (C) Two-photon imaging in MQAE-loaded cerebellar neurons. Changes in fluorescence (top traces) and corresponding transmembrane currents (bottom traces) caused by 150-ms-long pressure applications of GABA. Note about 50-times slower fluorescent transients in comparison with currents. (Modified from Marandi et al., 2002). 
A relation between the $\mathrm{Cl}^{-}$concentration and the fluorescence intensity is described by the Stern-Volmer-equation:

$$
\frac{F_{0}}{F}=1+K_{\mathrm{SV}}\left[\mathrm{Cl}^{-}\right]
$$

where $F_{0}$ is the fluorescence in the absence of halide, $F$ is the fluorescence in the presence of halide and $K_{\mathrm{sv}}$ is the Stern-Volmer quenching constant (in $\mathrm{M}^{-1}$ ). From this equation the $\mathrm{EC}_{50}$, the concentration of $\mathrm{Cl}^{-}$causing a $50 \%$ decrease in fluorescence, is $1 / K_{\mathrm{SV}}$.

Table 1 shows values of the Stern-Volmer constant and corresponding $\mathrm{EC}_{50}$ values for some quinolinium indicators. The mostused quinolinium indicators are 6-methoxy-N-(3-sulfopropyl) quinolinium (SPQ), 6-methoxy-N-ethylquinolium (MEQ) and $\mathrm{N}$-(6-methoxyquinolyl)-acetoethyl ester (MQAE).

The first designed quinolinium-based $\mathrm{Cl}^{-}$indicators was SPQ (Wolfbeis and Urbano, 1983; Illsley and Verkman, 1987; Figure 2A, Table 1). SPQ is excited at ultraviolet wavelengths with absorbance maxima at $318 \mathrm{~nm}$ and $350 \mathrm{~nm}$. This fluorescent dye has a single broad emission peak centred at $450 \mathrm{~nm}$ with a quantum yield of 0.69 in the absence of halides. In aqueous buffers the Stern-Volmer constant for quenching of SPQ by Cl- is $118 \mathrm{M}^{-1}$, giving $\mathrm{EC}_{50} \sim 8.5 \mathrm{mM}$. The fluorescence of SPQ is not altered by cations, phosphate, nitrate or sulfate, but it is quenched weakly by other monovalent anions including citrate, acetate, gluconate and bicarbonate (Illsley and Verkman, 1987; Krapf et al., 1988b; Jayaraman et al., 1999).

MQAE, the other quinolinium-based dye, which has been used in a number of studies during recent years, has high $\mathrm{Cl}^{-}$sensitivity (Figure 2A, Table 1) and, unlike SPQ, easily permeates through the plasma membrane (Mansoura et al., 1999). As a result the time of incubation with this dye can be rather short. For instance, 10-min incubation of brain slices is sufficient for bright staining of neurons (Marandi et al., 2002). However, this substance has to be used with prudence, as incubation of slices for 30-45 min caused a deterioration in the properties and even death of many neurons in neocortex and hippocampal slices (Holmgren, Zilberter, Mukhtarov, personal observations). For these reasons, results obtained after as long as 1-2 h of treatment with MQAE (e.g. Servetnyk and Roomans, 2007) have to be interpreted with caution. The other disadvantages of this dye lie in the significant leakage rate and bleaching. The leakage rate seems to be preparation-specific, ranging from $3 \%$ per hour in liposomes (Verkman et al., 1989) to 30\% per hour in brain slices (Marandi et al., 2002).

Quinolinium-based $\mathrm{Cl}^{-}$indicators have been used for measurements of $\mathrm{Cl}^{-}$in a variety of preparations, including isolated growth cones (Fukura et al., 1996), neurons (Schwartz and Yu, 1995; Inglefield and Schwartz-Bloom, 1997; Dallwig et al., 1999; Frech et al., 1999; Marandi et al., 2002), glia (Bevensee et al., 1997), different types of epithelial cells (Krapf et al., 1988b; Lau et al., 1994), fibroblasts (Chao et al., 1989; Woll et al., 1996; Munkonge et al., 2004), human gastric cancer cells (Miyazaki et al., 2008) and pancreatic beta-cells (Eberhardson et al., 2000). In general, quinolinium compounds have relatively good sensitivity and selectivity to $\mathrm{Cl}^{-}$and rapid responses to changes in $\mathrm{Cl}^{-}$. They are also insensitive to physiological changes in $\mathrm{pH}$.

The major disadvantage of these probes comes from their spectral properties, i.e. excitation at ultraviolet wavelengths. As a result, they are prone to strong bleaching (Inglefield and SchwartzBloom, 1997; Nakamura et al., 1997, Figure 2B). This restricts the duration of the measurements and allows only a very low data acquisition rate (0.2-2 frames per minute) (Inglefield and SchwartzBloom, 1997; Fukuda et al., 1998; Sah and Schwartz-Bloom, 1999). However, the use of these dyes in combination with two-photon microscopy strongly reduces bleaching and, consequently, photochemical damage (Marandi et al., 2002; Funk et al., 2008).

\section{GENETICALLY ENCODED Cl- INDICATORS YFP AS A TOOL FOR INTRACELLULAR CI MONITORING}

An alternative to exogenously added indicators is the use of an endogenously expressed chromophore such as green fluorescent protein (GFP). Using appropriate targeting sequences, GFPs have been directed selectively to numerous intracellular sites. Various applications of GFP in physiological studies of living cells have been described (Tsien, 1998; Zaccolo and Pozzan, 2000; Bizzarri et al., 2009). GFP derivatives with different colors have been used in FRET models to monitor $\mathrm{Ca}^{2+}$ (Miyawaki et al., 1997, 1999), $\mathrm{pH}$ (Kneen et al., 1998; Llopis et al., 1998; Miesenbock et al., 1998) and protein-protein interactions (Heim, 1999).

During the last decade, a new method of noninvasive $\left[\mathrm{Cl}^{-}\right]_{\mathrm{i}}$ monitoring using genetically encoded optical probes has been developed. This approach is based on the halide-binding properties of yellow

Table 1 | Structures and chloride sensitivity of some quinoline-based $\mathrm{Cl}^{-}$fluorescent indicators.

\begin{tabular}{|c|c|c|c|c|c|}
\hline IUPAC name & $\mathbf{R}_{1}$ & $\mathbf{R}_{2}$ & $\mathrm{~K}_{s v}\left(\mathrm{M}^{-1}\right)$ & $\mathrm{EC}_{50}(\mathrm{mM})$ & References \\
\hline 6-Methoxy-N-ethylquinolinium (MEQ) & $\mathrm{OCH}_{3}$ & $\mathrm{C}_{2} \mathrm{H}_{5}$ & 145 & 7 & Biwersi and Verkman, 1991 \\
\hline \multirow{3}{*}{$\begin{array}{l}N \text {-(Ethoxycarbonyl methyl)-6-methoxy } \\
\text { quinolinium (MQAE) }\end{array}$} & \multirow[t]{3}{*}{$\mathrm{OCH}_{3}$} & \multirow[t]{3}{*}{$\mathrm{CH}_{2} \mathrm{COOC}_{2} \mathrm{H}_{5}$} & 200 & 5 & Verkman et al., 1989 \\
\hline & & & $77^{*}$ & 13 & Marandi et al., 2002 \\
\hline & & & $24.7^{\#}$ & 40 & \\
\hline 6-methoxy-N-(-3-sulfopropyl)quinolinium (SPQ) & $\mathrm{OCH}_{3}$ & $\left(\mathrm{CH}_{2}\right)_{3} \mathrm{SO}_{3}^{-}$ & 118 & 8.5 & Krapf et al., $1988 b$ \\
\hline 6-methyl-N-(-3-sulfopropyl)quinolinium & $\mathrm{CH}_{3}$ & $\left(\mathrm{CH}_{2}\right)_{3} \mathrm{SO}_{3}^{-}$ & 83 & 12 & Krapf et al., 1988b \\
\hline 6-methoxy-N-(-4-sulfobutyl)quinolinium & $\mathrm{OCH}_{3}$ & $\left(\mathrm{CH}_{2}\right)_{4} \mathrm{SO}_{3}^{-}$ & 78 & 13 & Krapf et al., 1988b \\
\hline 6-methoxy-N-(-8-octanoic acid) quinolinium $\mathrm{Br}^{-}$ & $\mathrm{OCH}_{3}$ & $\left(\mathrm{CH}_{2}\right)_{7} \mathrm{COOH}$ & 52 & 19 & Geddes et al., 1999 \\
\hline 6-methoxy-N-(-11-undecanoic acid)quinolinium $\mathrm{Br}$ & $\mathrm{OCH}_{3}$ & $\left(\mathrm{CH}_{2}\right)_{10} \mathrm{COOH}$ & 34 & 29 & Geddes et al., 1999 \\
\hline 6-methoxy-N-(-15-pentadecanoic acid)quinolinium $\mathrm{Br}$ & $\mathrm{OCH}_{3}$ & $\left(\mathrm{CH}_{2}\right)_{14} \mathrm{COOH}$ & 34 & 29 & Geddes et al., 1999 \\
\hline
\end{tabular}

*Data from experiments in vitro. \#Hippocampal pyramidal rat neurones P9. (Modified from Geddes et al., 2001). 
fluorescent protein (YFP) and it derivatives (Wachter and Remington, 1999; Jayaraman et al.,2000).YFP is a derivative of GFP, which contains four point mutations (T203Y/S65G/V68L/S72A). It has improved brightness and red-shifted excitation/emission spectra compared with GFP (Ormo et al., 1996; Elsliger et al., 1999). The halide sensitivity of YFP was conferred on this protein using a rational mutagenesis strategy based upon crystallographic data (Wachter et al., 1998) and confirmed experimentally (Wachter and Remington, 1999).

It was found that YFP fluorescence is sensitive to various small anions with relative potencies $\mathrm{F}^{-}>\mathrm{I}^{-}>\mathrm{NO}_{3}^{-}>\mathrm{Cl}^{-}>\mathrm{Br}^{-}>$ formate $^{-}>$acetate $^{-}$(Jayaraman et al., 2000). YFP sensitivity to these small anions results from ground-state binding near the chromophore (Jayaraman and Verkman, 2000), which apparently alters the chromophore ionization constant and hence the fluorescence emission. As with other GFP derivatives, the fluorescence of YFP is $\mathrm{pH}$-dependent. The $\mathrm{EC}_{50}$ values for $\mathrm{Cl}^{-}$varied from $32.5 \mathrm{mM}$ $(\mathrm{pH}=6)$ to $777 \mathrm{mM}(\mathrm{pH}=7.5)$ (Table 2).

This analysis demonstrates that at the physiological range of intracellular $\mathrm{pH}(7.2-7.4)$ the sensitivity of YFP to $\mathrm{Cl}^{-}$is low, which creates difficulties and limitations in using "wild type" (WT) YFP

Table 2 | Sensitivity of YFP and YFP-H1480 to chloride (Modified from Wachter et al., 2000).

\begin{tabular}{lll}
\hline $\mathbf{p H}$ & $\mathbf{E C}_{\mathbf{5 0}}$ YFP (mM) & EC $_{\mathbf{5 0}}$ YFP-H1480 (mM) \\
\hline 6.0 & 32.5 & 22.1 \\
6.5 & 82.1 & 34.0 \\
7.0 & 245 & 66.2 \\
7.5 & 777 & 154.4 \\
8.0 & 2160 & 431
\end{tabular}

Table 3 | Intracellular chloride in different preparations registered by different methods.

\begin{tabular}{|c|c|c|c|}
\hline Preparation & Method & {$\left[\mathrm{Cl}^{-}\right]_{\mathrm{i}}(\mathrm{mM})$} & References \\
\hline Snail neurons & Cl-sensitive microelectrodes & $3-8$ & Neild and Thomas, 1974 \\
\hline Rabbit epithelial cells & Cl-sensitive microelectrodes & 16 & Abdulnour-Nakhoul et al., 2002 \\
\hline Rat sympathetic neurons & Cl-sensitive microelectrodes & 30 & Ballanyi and Grafe, 1985 \\
\hline Retina bipolar cells & Perforated patch & $21-25$ & Billups and Attwell, 2002 \\
\hline Hippocampal slices (P16-P20) & Perforated patch & $6-12$ & Khirug et al., 2008 \\
\hline Salamandra cones & Perforated patch & $20-50$ & Thoreson and Bryson, 2004 \\
\hline Spinal neurons & Perforated patch & $11-27$ & Rohrbough and Spitzer, 1996 \\
\hline Retina bipolar cells & Perforated patch & $8-23$ & Satoh et al., 2001 \\
\hline Retina amacrine and ganglion cells & Perforated patch & $14-29$ & Zhang et al., 2006 \\
\hline Hippocampal slices & Cell attach & $4-18$ & Tyzio et al., 2006 \\
\hline Hippocampal cultures & MQAE & $11-35$ & Hara et al., 1992, 1993 \\
\hline Epithelial cells & SPQ & 27 & Krapf et al., 1988a \\
\hline Renal cells & MQAE and flow cytometry & 43 & Miyazaki et al., 2007 \\
\hline Cockroach salivary gland cells & MQAE and two-photon fluorescence lifetime imaging & $42-80$ & Hille et al., 2009 \\
\hline Human neurophils & Zimosan-conjugated $\mathrm{Cl}$ probe & 73 & Painter and Wang, 2006 \\
\hline Hippocampal slices & Clomeleon & $5-30$ & Berglund et al., 2008 \\
\hline Hippocampal culture & Clomeleon & $20-60$ & Kuner and Augustine, 2000 \\
\hline Retina bipolar cells & Clomeleon & $10-60$ & Duebel et al., 2006 \\
\hline Hippocampal neurons & Cl-Sensor & 11 & Markova et al., 2008 \\
\hline $\mathrm{CHO}$ cells & Cl-Sensor & 23 & Markova et al., 2008 \\
\hline Retina photoreceptor cells & Cl-Sensor & $30-50$ & Markova et al., 2008; Mukhtarov et al., 2008 \\
\hline
\end{tabular}

as a $\mathrm{Cl}^{-}$indicator. Indeed, different methods of $\left[\mathrm{Cl}^{-}\right]_{\mathrm{i}}$ estimation in various cell types gives its range of variations from 3 to $60 \mathrm{mM}$ (Table 3). Consequently, the resolution of the indicator with $\mathrm{EC}_{50}$ more then $100 \mathrm{mM}$ is low and it can lead to errors in noninvasive estimation of $\left[\mathrm{Cl}^{-}\right]_{\mathrm{i}}$.

To further improve spectral characteristics, YFP was subjected to additional mutagenesis and the most successful variants were selected. It has been demonstrated that at $\mathrm{pH} 7.5$ the $\mathrm{EC}_{50}$ for $\mathrm{Cl}^{-}$of the mutant YFP H148Q is 154 mM (Table 2; Wachter et al., 2000), which is still high; however, it is closer to the physiological range of $\left[\mathrm{Cl}^{-}\right]_{\mathrm{i}}$ than WT YFP $(777 \mathrm{mM})$.

To enhance sensitivity of YFP-H148Q to $\mathrm{Cl}^{-}$, libraries of mutants were generated in which pairs of residues in the vicinity of the halide binding site were randomly mutated (Galietta et al., 2001a). Analysis of over a thousand clones revealed improved anion sensitivity with

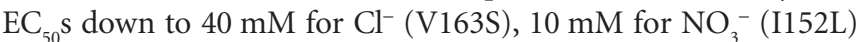

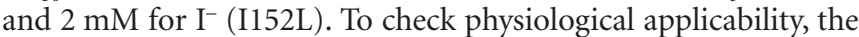
I152L mutant, which exhibited the best $\mathrm{I}^{-}$and $\mathrm{NO}_{3}{ }^{-}$sensitivities, was expressed in Swiss 3T3 fibroblasts carrying CFTR. Transfected cells were brightly fluorescent with a uniform cytoplasmic and nuclear staining pattern. Replacement of $20 \mathrm{mM} \mathrm{Cl}^{-}$with $\mathrm{I}^{-}$produced a fluorescence decrease of $53 \pm 2 \%$ with YFP-I152. It was much greater than that of $<10 \%$ for the same experiment with YFP-H148Q, indicating that this mutant is a good tool for monitoring $\mathrm{I}^{-}$and $\mathrm{NO}_{3}^{-}$. The same results were obtained when the activity of CFTR was studied using a Cl${ }^{-} / \mathrm{NO}_{3}{ }^{-}$exchange protocol (Galietta et al., 2001b).

Some other mutants of YFP also showed greatly improved $\mathrm{Cl}^{-}$ sensitivities (Table 4), which stimulated further development of $\mathrm{Cl}^{-}$ indicators. It provided the basis for using YFP mutants as genetically encoded $\mathrm{Cl}^{-}$sensors that can be targeted to specific organelles in living cells or expressed in specific cell types for monitoring $\left[\mathrm{Cl}^{-}\right]_{\mathrm{i}}$ distribution, to study the functioning of $\mathrm{Cl}^{-}$channels and pumps. 
Table 4 | Sensitivity of YFP mutants to chloride at pH 7.5.

\begin{tabular}{ll}
\hline Mutant & EC $_{\mathbf{5 0}}$ (mM) \\
\hline H148O & $106^{\mathrm{a}-197}$ \\
H148Q/1152L & $85^{\mathrm{a}}-88$ \\
H148QN150A/I52L & 61 \\
H148QN163S & $39^{\mathrm{a}-62}$ \\
H148QN163L & 77 \\
H148QN163T/F165Y & 55 \\
H148QN150SN163T & 92 \\
\hline
\end{tabular}

${ }^{a}$ Purified protein. $E C_{50}$ was measured in bacterial lysate with YFP-H148Q containing additional single or double mutations. (Modified from Galietta et al., 2001a).

\section{APPLICATION OF YFP IN HIGH-THROUGHPUT SCREENING}

In a number of experimental models YFP derivatives have been used as suitable probes for high-throughput (HTP) screening. These allow the testing of tens of thousands of different compounds (Ma et al., 2002a,b). We present here several examples.

YFP-H148Q was transfected in Fisher rat thyroid cells (FRT) and in Swiss 3T3 fibroblasts for quantitative HTP screening of potential modulators of CFTR halide permeances (Galietta et al., 2001b). In these assays small increases in CFTR activity by the agonists forskolin and genistein were detected. Because YFP fluorescence is sensitive to $\mathrm{H}^{+}$a simultaneous monitoring of $\mathrm{pH}$ by specific pH-probe, BCECF, was also conducted (Galietta et al., 2001b). Using HTP screening on cells expressing the YFP-H148Q mutant, new classes of CFTR modulators were identified: inhibitors (Ma et al., 2002a), activators (Galietta et al., 2001c; Ma et al., 2002b; Muanprasat et al., 2004, 2007), potentiators (Yang et al., 2003) and correctors (Pedemonte et al., 2005a,b) of wild-type CFTR, as well as of $\triangle F 508-C F T R$, the major CFTR mutation causing cystic fibrosis (see rev. Verkman and Galietta, 2009).

To screen potential activators of CFTR-mediated $\mathrm{Cl}^{-}$flux, a YFP mutant with higher halide sensitivity (YFP-H148Q/I152L) has been co-expressed with defective $\Delta$ F508-CFTR in FRT epithelial cells (Yang et al., 2003; Xu et al., 2008). It has been shown that natural cumarine compounds rescue defective $\Delta$ F508-CFTR chloride channel gating (Xu et al., 2008).

A mutant with enhanced sensitivity to halides (YFP-V163S) has been used in $\mathrm{M} 1$ cortical collecting-duct cells to monitor changes in $\mathrm{Cl}^{-}$mediated by CFTR or by stimulation with cAMP- and $\mathrm{Ca}^{2+}$ increasing agonists (Adam et al., 2005).

Important observations have been obtained with YFP-H148Q/ I152L, which shows a 30 -fold selectivity to $\mathrm{I}^{-}$over $\mathrm{Cl}^{-}$. It was proved to be a sensitive biosensor of $\mathrm{Na}^{+} / \mathrm{I}^{-}$symporter-mediated $\mathrm{I}^{-}$uptake in thyroid cells and nonthyroidal cells following gene transfer (Rhoden et al., 2007, 2008). As defective iodide transport occurs in several inherited and acquired thyroid disorders, using this YFP mutant for detection of $\mathrm{I}^{-}$represents a useful tool for studying the pathophysiology and pharmacology of this $\mathrm{Na}^{+} / \mathrm{I}^{-}$symporter (Rhoden et al., 2007).

YFP derivatives were also used for testing ligands of glycine receptors (GlyRs) and ionotropic GABA receptors. Using HEK 293 cells expressing YFP-I152L or YFP-V163S mutants with these $\mathrm{Cl}^{-}$-selective receptor-operated channels has established the optimal conditions for pharmacological screening of $\mathrm{Cl}^{-}$(Kruger et al.,
2005) and detection of functional and non-functional mutations in the GlyRs (Gilbert et al., 2009).

These observations have demonstrated advantages of using genetically encoded YFP derivatives in HTP in comparison with other techniques.

\section{ADVANTAGES AND DISADVANTAGES OF GENETICALLY ENCODED $\mathrm{Cl}^{-}$INDICATORS}

Of the many advantages of YFP-based $\mathrm{Cl}^{-}$indicators in comparison with fluorescent dyes, we will mention only the four most important.

First, the peak of absorbance is at a wavelength of more then $480 \mathrm{~nm}$, i.e., in contrast to quinolinium-based halide indicators, YFP can be excited in the visible range, permitting more stable fluorescence signal and less cell damage. Consequently, it allows longlasting $\mathrm{Cl}^{-}$monitoring with repetitive stable responses and bright fluorescence signals using conventional imaging equipment.

Second, genetically encoded probes can be targeted to specific cell types by cell-specific promoter, or to defined cellular compartments by fusion to short sequence tags or to specific proteins. This would allow $\mathrm{Cl}^{-}$monitoring in specific cell types or cellular compartments. For instance, transgenic mice expressing enhanced YFP (EYFP) under control of the Kv3.1 $\mathrm{K}^{+}$channel promoter (pKv3.1) have been generated (Metzger et al., 2002), making possible neuron-specific expression of EYFP in the hippocamus, thalamus and granule cell layer of cerebellum. This model has been used for analysis of glutamateinduced changes in intracellular $\mathrm{Cl}^{-}$and $\mathrm{pH}$ (Metzger et al., 2002; Slemmer et al., 2004). The thyl promoter has been successfully used to drive specific neuronal expression of Clomeleon in the hippocampus and in neocortical areas as well as in the dentate gyrus, cerebellar mossy fibers and piriform cortex (Berglund et al., 2008).

Third, the intracellular concentration of the YFP-based $\mathrm{Cl}^{-}$indicators is only a few micromolar, which is several orders of magnitude less than the $\left[\mathrm{Cl}^{-}\right]_{i}$. This avoids buffering effects, which are a substantial problem in, for instance, fluorescence measurements of intracellular $\mathrm{Ca}^{2+}$ at using conventional fluorescent dyes.

Finally, the molecular weight of the YFP-based $\mathrm{Cl}^{-}$indicators is about $27 \mathrm{kDa}$, which prevents diffusion of the indicator from cells. In cells that are imaged without simultaneous electrophysiological recordings, indicator levels remains constant over hours.

YFP-based sensors also have several disadvantages. One of them is $\mathrm{pH}$ sensitivity (Table 2). Changes in intracellular $\mathrm{pH}$ or in specific compartments can lead to errors in observations and interpretation of results. To overcome this problem, in some cases independent monitoring of $\mathrm{pH}$ is necessary.

YFP-based $\mathrm{Cl}^{-}$sensors have rather low kinetics of $\mathrm{Cl}^{-}$association/ dissociation. The double mutant YFP-H148Q/V163S, which exhibits relatively high $\mathrm{Cl}^{-}$sensitivity $\left(\mathrm{EC}_{50}=39 \mathrm{mM}\right)$, has an association time constant $\tau=1900 \mathrm{~ms}$ (Galietta et al., 2001a), which would cause limitations in the time resolution when using this mutant for analysis of rapid $\mathrm{Cl}^{-}$dynamics. The other double mutant, YFP-H148Q/I152L, has much faster association/dissociation kinetics (association time constant $\tau=52 \mathrm{~ms}$; Galietta et al., 2001a); however, its sensitivity to $\mathrm{Cl}^{-}$is relatively low $\left(\mathrm{EC}_{50}=85 \mathrm{mM}\right)$. Thus, the YFP-based probes can be used to reliably detect changes in $\mathrm{Cl}^{-}$ concentrations with time course resolution in the range of hundreds of milliseconds or even seconds. 
A significant limitation in the use of $\mathrm{Cl}^{-}$indicators was a lack of a $\mathrm{Cl}^{-}$-dependent change in spectral shape, which precludes ratiometric measurements. For quinolinium-based $\mathrm{Cl}^{-}$-sensitive dyes, synthesis of a series of dual-wavelength fluorescent indicators has been achieved using conjugation of $\mathrm{Cl}^{-}$-sensitive and $\mathrm{Cl}^{-}$-insensitive dye molecules with different spacers (Jayaraman et al., 1999). Only one "chimera" (MQa4AQ) was cell-permeating and it turned out to be four times less $\mathrm{Cl}^{-}$-sensitive than MQAE. YFP-derivatives also do not have a clear isosbestic point in spectral shape at different $\mathrm{Cl}^{-}$concentrations. This precludes ratiometric measurements and, consequently, gives rise to limitations in the estimation of $\left[\mathrm{Cl}^{-}\right]_{i}$ values.

The important development of genetically encoded $\mathrm{Cl}^{-}$probes was achieved by Kuner and Augustine (2000), who constructed a ratiometric YFP-based $\mathrm{Cl}^{-}$indicator, termed Clomeleon.

\section{RATIOMETRIC MONITORING OF Cl- USING GENETICALLY ENCODED PROBES \\ Clomeleon}

Clomeleon consists of two fluorescent proteins, Cyan Fluorescence Protein (CFP) and a variant of YFP, Topaz Fluorescence Protein (TFP, GFP/S65G/S72A/K79R/T203Y/H231L), connected with a polypeptide linker of 24 aminoacids (Figures 3A,B).

The work of this probe is based on the phenomenon of Fluorescence Resonance Energy Transfer (FRET) between two fluorescent proteins (see Box 1). Binding of a $\mathrm{Cl}$ anion to TFP reduces its emission, leading to a decrease in FRET efficiency. This process can be visualized as a reduction in the ratio of fluorescence emission between the TFP acceptor and CFP donor fluorophores.
Analysis of emission spectra of this construct revealed that the intensity of fluorescence depends on $\mathrm{Cl}^{-}$concentration. Moreover, presence of the isosbestic point in normalized spectra (Figure 3C) allows the use of this indicator as a ratiometric probe for estimation of $\mathrm{Cl}^{-}$concentration (Figure 3D) The construct was named Clomeleon as an allusion to the FRET-based genetically encoded $\mathrm{Ca}^{2+}$ indicator, Cameleon (Miyawaki et al., 1997).

Unlike organic probes, Clomeleon possesses several valuable features: excitation at visible wavelengths, good signal-to-noise ratio, safer loading procedures for cells, absence of leakage from cells and the possibility of targeting the probe to different cell types using specific promoters. Moreover, the construct exhibits high fluorescence stability: absence of Clomeleon bleaching during $2 \mathrm{~h}$ of recording has been reported (Pond et al., 2006). Proteolitical stability of Clomeleon in transgenic mice has been observed during 9 months. It is also a low toxicity probe, which did not cause any behavioural aberration in Clomeleon-expressing mice in the course of 2 years (Berglund et al., 2006).

The main advantage of Clomeleon is the possibility of performing ratiometric measurements of $\left[\mathrm{Cl}^{-}\right]_{\mathrm{i}}$. The ratiometric capabilities of Clomeleon allow optical measurements that are minimally influenced by the thickness of the specimen, intensity of the excitation light and concentration of the indicator. This, in turn, makes it possible to accurately determine $\mathrm{Cl}^{-}$values even in cells with complicated geometry, such as neurons.

Clomeleon has been used for measurements of $\left[\mathrm{Cl}^{-}\right]_{\mathrm{i}}$ in cultured hippocampal neurons (Kuner and Augustine, 2000), in plant cells (Lorenzen et al., 2004) and in cells of retina and brain slices (Duebel et al., 2006; Pond et al., 2006). The widest field

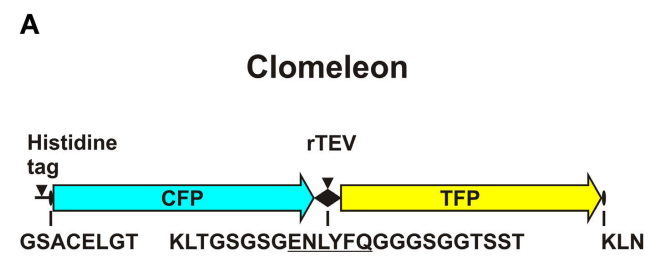

B

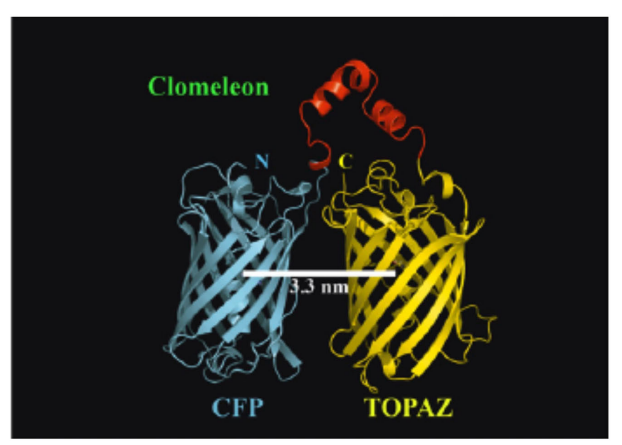

FIGURE 3 | Structure and fluorescence properties of Clomeleon.

(A) Scheme of Clomeleon construct and (B) schematic reconstruction of Clomeleon structure. The fluorescent domains, CFP (cyan) and Topaz (yellow) were set in parallel orientation as $\mathrm{N}$ - and $\mathrm{C}$-terminal ends of either domain were on the same site. The distance between CFP and Topaz chromophores was calculated to be $3.3 \mathrm{~nm}$. (From Kuner and Augustine, 2000 (top) and
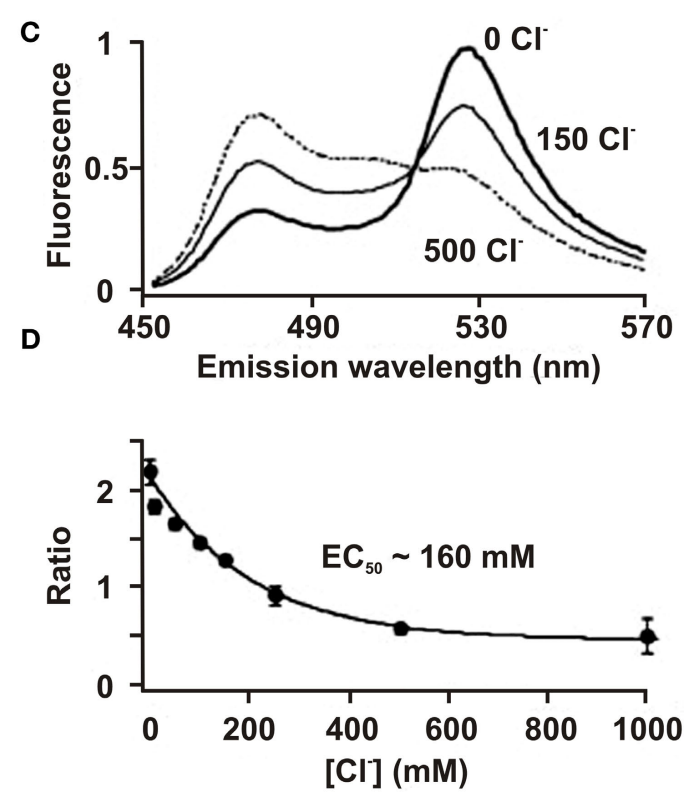

Jose et al., 2007 (bottom). (C) Emission spectra of Clomeleon in the presence of different $\mathrm{Cl}^{-}$concentrations. In all cases, the recombinant protein was excited at $434 \mathrm{~nm}$ and the emission spectra were normalized to their peaks at $527 \mathrm{~nm}$. (D) The relationship between fluorescence emission ratio $\left(527 \mathrm{~nm} / 485 \mathrm{~nm}\right.$ ) and $\mathrm{Cl}^{-}$concentrations. (Data from Kuner and Augustine, 2000). 


\section{BOX 1 | FRET.}

Phenomenon of fluorescence resonance energy transfer (FRET) represents interaction between two fluorophores, when excitation energy from a donor (D) molecule is directly transferred to a molecule of acceptor (A).

Four main conditions have to be fulfilled for this phenomenon development:

(i) overlapping of emission spectrum of donor and excitation spectrum of acceptor;

(ii) small distance between molecules (less then $10 \mathrm{~nm}$ );

(iii) good orientation the dipole moments of donor emission and acceptor absorption;

(iv) high quantum yield of fluorophores.

The FRET efficiency $(E$ ) is dependent on the inverse sixth power of the distance between fluorophores $(r)$ :

$E=1 /\left[1+\left(r / R_{0}\right)^{6}\right]$

where $R_{0}$ is the distance at which the energy transfer efficiency is $50 \%$.

This makes FRET technique a sensitive tool for analysis of proteinprotein interaction and changes in intermolecular distances.

For more details see: Tsien et al., 1993; Pollok and Heim, 1999; Jares-Erijman and Jovin, 2003; Sekar and Periasamy, 2003; Wallrabe and Periasamy, 2005.
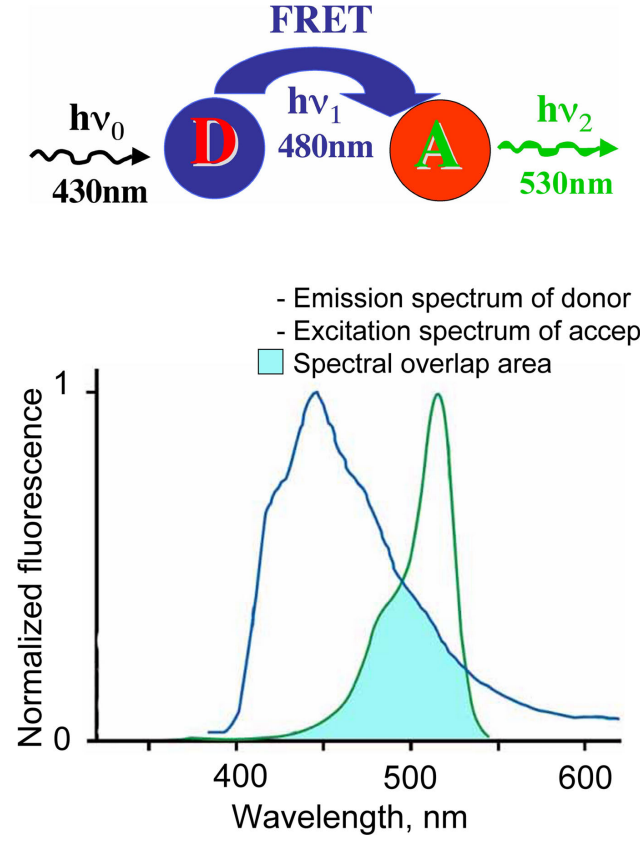

of application for genetically encoded probes comes from the possibility of targeting them to specific cell types using unique promoters, or to cellular compartments and membrane domains by fusion to respective tags or to proteins with known location. Several transgenic mouse lines have been created by insertion of Clomeleon, under control of the thyl promoter, into their genome (Berglund et al., 2008). Details and functional implications of these models are described in recent papers (Duebel et al., 2006; Berglund et al., 2008).

Potential limitations of this probe are that it, as other YFP-based $\mathrm{Cl}^{-}$indicators, is sensitive to $\mathrm{pH}$ and that the time course of reaction to $\mathrm{Cl}^{-}$is relatively slow. The other potential problem is that the fluorophores, CFP and TFP, may bleach at different rates, which would distort the calibration of the indicator signal.

The important disadvantage of Clomeleon is that at physiological $\mathrm{pH}$ it has a rather low sensitivity to $\mathrm{Cl}^{-}$. The $\mathrm{EC}_{50}$ of Clomeleon is more than $160 \mathrm{mM}$ (Kuner and Augustine, 2000; Figure 3D, Table 5) which is far from physiological $\left[\mathrm{Cl}^{-}\right]_{\mathrm{i}}(3-60 \mathrm{mM})$. For this reason, the development of ratiometric probes with high sensitivity to $\mathrm{Cl}^{-}$is required.

\section{Cl-Sensor}

Recently a new genetically encoded indicator, termed Cl-Sensor, has been proposed (Markova et al., 2008; Figure 4A). Analysis of the spectral properties of this construct during simultaneous monitoring of fluorescence signals and whole-cell recordings with different $\mathrm{Cl}^{-}$concentrations in the pipette solution revealed two important features.

First, the normalized excitation spectra obtained at different $\left[\mathrm{Cl}^{-}\right]_{\text {i }}$ have a common point near $465 \mathrm{~nm}$ (Figure 4B), meaning that $\mathrm{Cl}$ Sensor allows ratiometric monitoring using the fluorescence excitation ratio. This feature allows recordings using conventional setups with devices for a rapid change of excitation wavelength.
Table 5 | Halide sensitivity and ionic selectivity of Clomeleon (Modified from Kuner and Augustine, 2000).

\begin{tabular}{lcc}
\hline Halide & $\mathbf{E C}_{\mathbf{5 0}}(\mathbf{m M})$ & Hill coefficient \\
\hline $\mathrm{F}^{-}$ & $5.9 \pm 2.4$ & $1.25 \pm 0.09$ \\
$\mathrm{I}^{-}$ & $46 \pm 14$ & $0.90 \pm 0.07$ \\
$\mathrm{Br}^{-}$ & $111 \pm 21$ & $0.82 \pm 0.09$ \\
$\mathrm{Cl}^{-}$ & $167 \pm 13$ & $0.87 \pm 0.07$
\end{tabular}

Second, due to triple YFP mutation (YFP-H148Q/I152L/V163S) this construct exhibits a relatively high sensitivity to $\mathrm{Cl}^{-}$with an estimated $\mathrm{EC}_{50}$ of about $30 \mathrm{mM}(28 \pm 5 \mathrm{mM})$. With about 5 -fold higher sensitivity than Clomeleon, this indicator has a good dynamic range at physiological intracellular concentrations (Figure 4C), providing a good basis for reliable monitoring of $\left[\mathrm{Cl}^{-}\right]_{\mathrm{i}}$ in different cell types.

$\mathrm{Cl}$-Sensor demonstrates the same advantageous features as Clomeleon, i.e. excitation at visible wavelengths, good signal-to-noise ratio, safer loading procedures, absence of leakage from cells and ability to be targeted to different cell types using specific promoters.

Similarly to other fluorescent proteins from the GFP family, ClSensor exhibits a relatively high $\mathrm{pH}$ sensitivity with $\mathrm{pKa}$ ranging from 7.1 to $8.0 \mathrm{pH}$ units at different $\mathrm{Cl}^{-}$concentrations.

One widespread problem with GFPs is their low transfection efficiency in neurons. To overcome this difficulty, Cl-Sensor was subcloned at two different vectors driven by mutated CMV and ubiquitine promoter. These plasmids carrying $\mathrm{Cl}$-Sensor reveal higher transfection efficiency and brightness of probe in the $\mathrm{CHO}$ cell line, retinal cells and spinal or hippocampal neurons (Waseem et al., paper in preparation).

The Cl-Sensor was used for noninvasive estimation of $\left[\mathrm{Cl}^{-}\right]_{\mathrm{i}}$ in $\mathrm{CHO}$ cells, hippocampal neurons and photoreceptor cells from retinal slices (Table 3; Markova et al., 2008; Mukhtarov et al., 


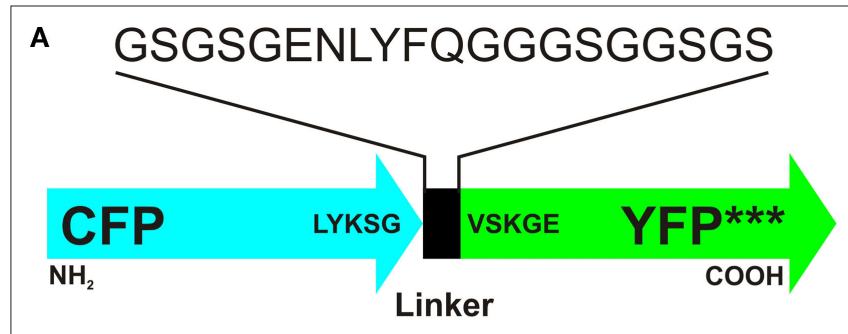

B
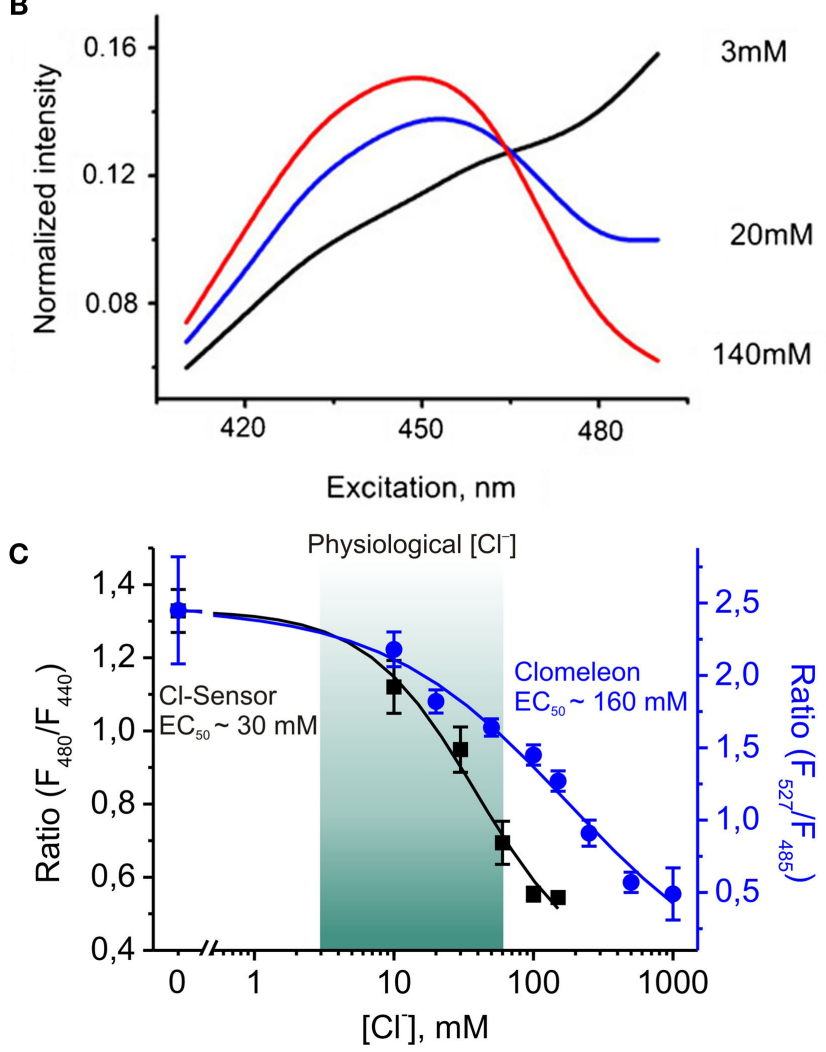

FIGURE 4 | Design and fluorescence properties of Cl-Sensor.

(A) Schematic representation of $\mathrm{Cl}$-Sensor construct; ${ }^{* * *}$ indicates three mutations: YFP-H148Q, $-1152 \mathrm{~L}$ and -V163S in the YFP sequence. (B) Normalized spectra of $\mathrm{Cl}$-Sensor. Whole-cell recordings from $\mathrm{CHO}$ cells with pipettes containing different $\mathrm{Cl}^{-}$concentrations (shown in the graph). Note that spectra have a common point at $465 \mathrm{~nm}$. (C) Comparison of $\mathrm{Cl}^{-}$-sensitivities of $\mathrm{Cl}-\mathrm{Sensor}$ and Clomeleon. Cl-Sensor (black squares and line): the relationship between fluorescence excitation ratio $\left(F_{480} / F_{440}\right)$ and $\left[\mathrm{Cl}^{-}\right]_{i}$ obtained from whole-cell recordings with pipettes containing solutions with different $\mathrm{Cl}^{-}$ concentrations (from 0 to $150 \mathrm{mM}$ ) (from Markova et al., 2008). Clomeleon (blue circles and line): the relationship between fluorescence emission ratio $\left(F_{527} / F_{485}\right)$ and $\left[\mathrm{Cl}^{-}\right]_{\mathrm{i}}$ plotted from Kuner and Augustine, 2000 (see Figure 4D). Note that main part of calibration curve for Clomeleon is out of physiological range of $\left[\mathrm{Cl}_{i}^{-}\right]_{\text {. }}$

2008). For Cl-Sensor gene delivery to retinal cells an in vivo electroporation technique was used (Matsuda and Cepko, 2004; Mukhtarov et al., 2008). The efficiency of electroporation into the developing postnatal retina (at P0) was high, and transgene expression persisted for more then 1 month (Mukhtarov et al., 2008), indicating that in vivo electroporation of Cl-Sensor cDNA is a powerful tool for monitoring $\left[\mathrm{Cl}^{-}\right]_{\mathrm{i}}$ under different experimental conditions and through age-dependent changes in $\mathrm{Cl}^{-}$in neurons.

\section{BioSensor-GlyR - tool for monitoring $\mathrm{Cl}^{-}$-selective} channel activation

Investigation of brain functioning requires methods allowing dynamic analysis of network activity combined with determination of single-cell properties. This strategy has been developed for monitoring calcium transients using rapid two-photon microscopy (Cossart et al., 2005). Chemically engineered proteins that are directly sensitive to light are also powerful optical methods of protein function control for modulation of signalling circuits inside cells and in cell circuits (Gorostiza and Isacoff, 2008). However, analysis of networks formed by neuronal circuits for specific synapses (glutamatergic, GABAergic or glycinergic) is hampered by lack of adequate techniques. This problem could be solved by genetic incorporation of molecules capable of changing their fluorescence on activation of specific synapses. The best candidates for these molecules would be fluorescently modified postsynaptic receptor-operated channels. Genetic incorporation of a molecular domain which could change fluorescence upon channel activation would provide the possibility of noninvasive monitoring of ion channel activity. Development of these molecules is a highly challenging task.

One of the approaches uses the voltage-clamp fluorometry (VCF) technique, based on covalently attaching a small environmentally sensitive sulfhydryl-labeled fluorophore to a cysteine introduced into a domain of interest on the protein. This approach has been successfully used to analyze the conformational rearrangements underlying gating of voltage-gated potassium channels (Mannuzzu et al., 1996) and ligand-gated glycine receptor (GlyR) channels (Pless and Lynch, 2008, 2009).

The other way consists of inserting a genetically encoded fluorescent sensor in the protein's sequence without changing its functional properties. Recently, a new genetic probe, termed BioSensor-GlyR, has been developed (Mukhtarov et al., 2008). This construct is a $\mathrm{Cl}^{-}$-selective GlyR channel with $\mathrm{Cl}$-Sensor incorporated into the long cytoplasmic domain (Figure 5A).

The functioning of this modified GlyR is not perturbed by the inserted $\mathrm{Cl}$-Sensor. This fact was proved in whole-cell recordings of cells expressing BioSensor-GlyR, where rapid application of glycine elicited ionic currents with kinetics similar to those of wild-type GlyR (Figure 5B). The main functional properties of BioSensorGlyR, i.e. kinetics, agonist sensitivity and $\mathrm{Cl}^{-}$selectivity, are also similar to those of the wild-type GlyR.

Application of glycine to cells expressing BioSensor-GlyR induced changes in fluorescence (Figure 5C). The amplitude and direction of fluorescence signals correlated with the amplitude and direction of glycine-induced currents (Figure 5D), demonstrating that BioSensor-GlyR is a good probe for spectroscopic monitoring of GlyR activation in live cells. The sensitivity of BioSensor-GlyR was high enough to resolve changes in $\left[\mathrm{Cl}^{-}\right]_{\mathrm{i}}$ induced by activation of postsynaptic receptors in glycinergic synapses. The decay kinetics of fluorescence responses were slow compared with those of ionic currents. This might be partially due to the kinetics of $\mathrm{Cl}^{-}$binding by YFP. However, this may also reflect slow intracellular $\mathrm{Cl}^{-}$ transients, as monitoring with MQAE, the rapid quinolinium indicator, showed a similarly slow rise and decay of $\mathrm{Cl}^{-}$-dependent fluorescence in cerebellar neurons (see Figure 2C).

In spite of these limitations, BioSensor-GlyR is a promising tool for spectroscopic monitoring of $\left[\mathrm{Cl}^{-}\right]_{i}$ changes in the local surroundings of glycine receptor ion channels. Development of 
A

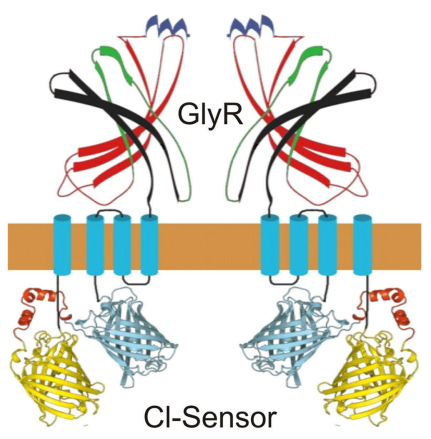

B

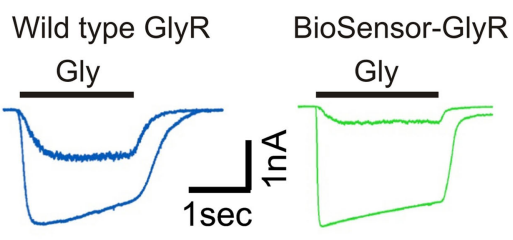

C

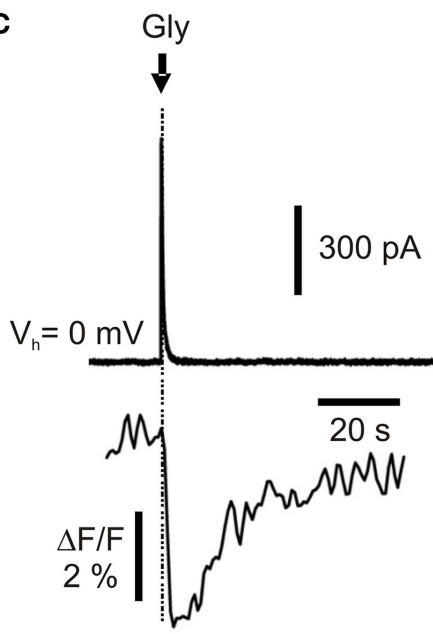

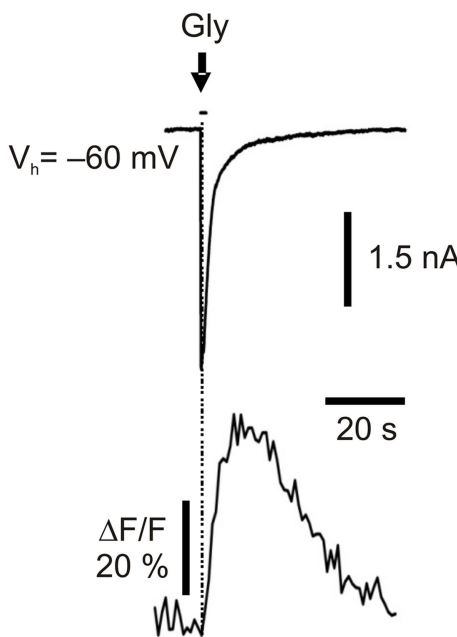

D

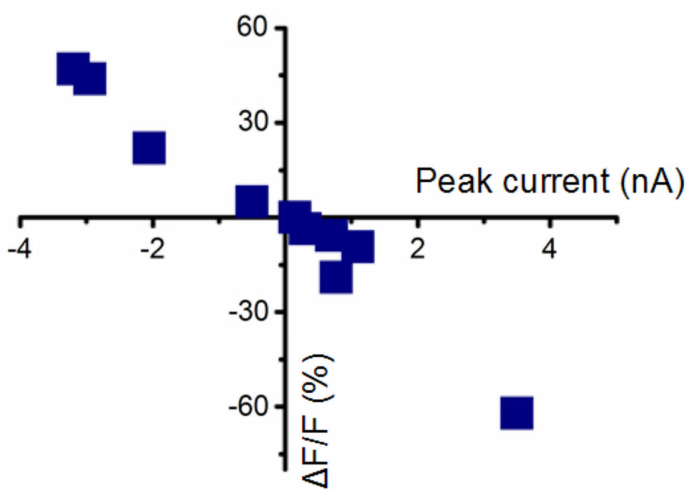

[Gly], $\mu \mathrm{M}$

FIGURE 5 | Structure and fluorescence properties of BioSensor-GlyR. (A) Scheme of BioSensor-GlyR construct. Two subunits are shown. (B) Wholecell currents induced by rapid application of glycine $(30$ or $300 \mu \mathrm{M})$ and doseresponse curves obtained from $\mathrm{CHO}$ cells transfected with either wild-type human GlyR (blue) or BioSensor-GlyR (green). Note similar kinetics and agonist sensitivity for wild-type GlyR and BioSensor-GlyR. (C) Examples of simultaneous

transgenic animals expressing Cl-Sensor and BioSensor-GlyR will be particularly useful for studies of inhibitory neuronal networks in brain slice preparations using two-photon microscopy. For the Biosensor-GlyR it might, however, be a difficult task as expression of the GlyR, containing an additional CFP-YFP module in the long cytoplasmic loop, may modify the function of glycinergic synapses.

\section{CONCLUSIONS}

The development of imaging techniques and specific genetically encoded chloride-sensitive probes has opened new avenues for noninvasive monitoring of this ion in different cell types and cellular compartments in normal and pathological conditions. The main steps stimulating the development of these probes were as follows. First, the discovery of the halide sensitivity of YFP. Second, the production of YFP mutants exhibiting usefully high sensitivity to $\mathrm{Cl}^{-}$

whole-cell and fluorescence recordings from BioSensor-GlyR transfected BHK cells with pipette containing either nominally 0 (left traces) or $150 \mathrm{mM}$ (right traces) $\mathrm{Cl}^{-}$. Glycine $(1 \mathrm{mM})$ was pressure applied for $10 \mathrm{~ms}$ duration. (D) Relationship between the amplitude of glycine-induced currents and changes in fluorescence of BioSensor-GlyR at $480 \mathrm{~nm}$. The amplitude of currents was regulated by the changing of $V_{h}$. (Modified from Mukhtarov et al., 2008). at concentrations close to the physiological range of $\left[\mathrm{Cl}^{-}\right]$. Third, the construction of molecules (Clomeleon and Cl-Sensor) consisting of two fluorescent proteins, allowing ratiometric noninvasive estimation of $\left[\mathrm{Cl}^{-}\right]_{i}$. Finally, the incorporation of $\mathrm{Cl}$-Sensor into the sequence of the $\mathrm{Cl}^{-}$-selective glycine receptor channel (BioSensorGlyR), which opens up the ability to monitor synaptic activation of these proteins using imaging techniques. This provides an intriguing background for the development of biosensors which make it possible to monitor the activity of ionotropic GABA receptors and other $\mathrm{Cl}^{-}$-selective channels.

\section{ACKNOWLEDGMENTS}

This work was supported by the NEUROCYPRES grant from the European Commission Seventh Framework Programme (for Tatyana Waseem and Marat Mukhtarov) and INSERM (Piotr Bregestovski). 


\section{REFERENCES}

Abdulnour-Nakhoul, S., Nakhoul, N. L., Caymaz-Bor, C., and Orlando, R. C. (2002). Chloride transport in rabbit esophageal epithelial cells. Am. J. Physiol. Gastrointest.Liver Physiol.282, G663-G675.

Adam, G., Ousingswart, J., Shreiber, R., and Kunzelmann, K. (2005). Increase in intracellular $\mathrm{Cl}^{-}$concentration by cAMP-and $\mathrm{Ca}^{2+}$-dependent stimulation of M1 collecting duct cells. Pflugers Arch. Eur. J. Physiol. 449, 470-478.

Aickin, C. C. (1981). A double-barrelled micro-electrode suitable for measurement of intracellular chloride activity (a 1) in guinea-pig vas deferens. J. Physiol. 320, 4P.

Aickin, C. C., and Brading, A. F. (1982). Measurement of intracellular chloride in guinea-pig vas deferens by ion analysis, ${ }^{36}$ chloride efflux and microelectrodes. J. Physiol. 326, 139-154.

Ascher, P., Kunze, D., and Neild, T. O. (1976). Chloride distribution in Aplysia neurones. J. Physiol. 256, 441-464.

Ashcroft, F. (2000). Ion Channels and Diseases. San Diego, Academic Press.

Ballanyi, K., and Grafe, P. (1985). An intracellular analysis of gammaaminobutyric-acid-associated ion movements in rat sympathetic neurones. J. Physiol. 365, 41-58.

Berglund, K., Schleich, W., Krieger, P., Loo, L. S., Wang, D., Cant, N. B., Feng, G., Augustine, G. J., and Kuner, T. (2006). Imaging synaptic inhibition in transgenic mice expressing the chloride indicator, Clomeleon. Brain Cell Biol. 35, 207-228.

Berglund, K., Schleich, W., Wang, H., Feng, G., Hall, W. C., Kuner, T., and Augustine, G. J. (2008). Imaging synaptic inhibition throughout the brain via genetically targeted Clomeleon. Brain Cell Biol. 36, 101-118.

Bevensee, M. O., Apkon, M., and Boron, W. F. (1997). Intracellular pH regulation in cultured astrocytes from rat hippocampus. II. Electrogenic $\mathrm{Na} /$ HCO3 cotransport. J. Gen. Physiol. 110, 467-483.

Bialek, S., Joseph, D. P., and Miller, S. S. (1995). The delayed basolateral membrane hyperpolarization of the bovine retinal pigment epithelium: mechanism of generation. J. Physiol. 484, 53-67.

Billups, D., and Attwell, D. (2002). Control of intracellular chloride concentration and GABA response polarity in rat retinal ON bipolar cells. J. Physiol. 545, 183-198.

Biwersi, J., and Verkman, A. S. (1991). Cell-permeable fluorescent indicator for cytosolic chloride. Biochemistry 30 , 7879-7883.
Bizzarri, R., Serresi, M., Luin, S., and Beltram, F. (2009). Green fluorescent protein based $\mathrm{pH}$ indicators for in vivo use: a review.Anal. Bioanal. Chem.393, 1107-1122.

Brown, A. M., Sutton, R. B., and Walker, J. L., Jr. (1970). Increased chloride conductance as the proximate cause of hydrogen ion concentration effects in Aplysia neurons. J. Gen. Physiol. 56, 559-582.

Chao, A. C., Dix, J. A., Sellers, M. C., and Verkman, A. S. (1989). Fluorescence measurement of chloride transport in monolayer cultured cells. Mechanisms of chloride transport in fibroblasts. Biophys. J. 56, 1071-1081.

Chen, P.Y., Illsley, N. P., and Verkman, A. S. (1988). Renal brush-border chloride transport mechanisms characterized using a fluorescent indicator. Am. J. Physiol. 254, F114-F120.

Chen, T. Y., and Hwang, T. C. (2008). CLC-0 and CFTR: chloride channels evolved from transporters. Physiol. Rev. 88, 351-387.

Cossart, R., Ikegaya, Y., and Yuste, R. (2005). Calcium imaging of cortical networks dynamics. Cell Calcium 37, 451-457.

Dallwig, R., Deitmer, J. W., and Backus, K. H. (1999). On the mechanism of GABA-induced currents in cultured rat cortical neurons. Pflugers Arch. 437, 289-297.

Davis, J. P., Chien, P. F., Chipperfield, A. R., Gordon, A., and Harper, A. A. (2000). The three mechanisms of intracellular chloride accumulation in vascular smooth muscle of human umbilical and placental arteries. Pflugers Arch. 441, 150-154.

Debellis, L., Papini, E., Caroppo, R. Montecucco, C., and Curci, S. (2001). Helicobacter pylori cytotoxin VacA increases alkaline secretion in gastric epithelial cells. Am. J. Physiol. Gastrointest. Liver Physiol. 281, G1440-G1448.

Dibbens, L. M., Harkin, L.A., Richards, M., Hodgson, B. L., Clarke, A. L., Petrou, S., Scheffer, I. E., Berkovic, S. F., and Mulley, J. C. (2009). The role of neuronal GABA(A) receptor subunit mutations in idiopathic generalized epilepsies. Neurosci. Lett. 453, 162-165.

Duebel, J., Haverkamp, S., Schleich, W., Feng, G., Augustine, G. J., Kuner, T., and Euler, T. (2006). Two-photon imaging reveals somatodendritic chloride gradient in retinal ON-type bipolar cells expressing the biosensor Clomeleon. Neuron 49, 81-84.

Eberhardson, M., Patterson, S., and Grapengiesser, E. (2000). Microfluorometric analysis of $\mathrm{Cl}^{-}$permeability and its relation to oscillatory
$\mathrm{Ca}^{2+}$ signalling in glucose-stimulated pancreatic beta-cells. Cell. Signal. 12, 781-786.

Elsliger, M. A., Wachter, R. M., Hanson, G. T., Kallio, K., and Remington, S. J. (1999). Structural and spectral response of green fluorescent protein variants to changes in pH. Biochemistry 38, 5296-5301.

Frech, M. J., Deitmer, J. W., and Backus, K. H. (1999). Intracellular chloride and calcium transients evoked by gamma-aminobutyric acid and glycine in neurons of the rat inferior colliculus. J. Neurobiol. 40 386-396.

Fukuda, A., Tanaka, M., Yamada, Y., Muramatsu, K., Shimano, Y., and Nishino, H. (1998). Simultaneous optical imaging of intracellular $\mathrm{Cl}^{-}$in neurons in different layers of rat neocortical slices: advantages and limitations. Neurosci. Res. 32, 363-371.

Fukura, H., Komiya, Y., and Igarashi, M. (1996).Signaling pathway downstream of GABAA receptor in the growth cone. J. Neurochem. 67, 1426-1434.

Funk, K., Woitecki, A., Franjic-Würtz, C., Gensch, T., Möhrlen, F., and Frings, S. (2008). Modulation of chloride homeostasis by inflammatory mediators in dorsal root ganglion neurons. Mol. Pain 4, 32.

Galietta, L. J. V., Haggie, P. M., and Verkman,A.S. (2001a). Green fluorescent protein-based halide indicators with improved chloride and iodide affinities. FEBS Lett. 499, 220-224.

Galietta, L. J. V., Jayaraman, S., and Verkman, A. S. (2001b). Cell-based assay for high-throughput quantitative screening of CFTR chloride transport agonists. Am. J. Physiol., Cell Physiol. 281, 1734-1742.

Galietta, L. J. V., Springsteel, M. F. Eda, M., Niedzinski, E. J., By, K., Haddadin, M. J., Kurth, M. J., Hantz, M., and Verkman, A. S. (2001c). Novel CFTR chloride channel activators identified by screening of combinatorial libraries based on flavone and benzoquinolizinium lead compounds. J. Biol. Chem. 276 19723-19728.

Geddes, C. D., Apperson, K., Karolin, J. and Birch, D. J. S. (2001). Chlodiesensitive fluorescent indicators. Anal. Biochem. 293, 60-66.

Geddes, C. D., Douglas, P., Moore, C. P. Wear, T. J., and Egerton, P. L. (1999). New Indolium and Quinolinium dyes sensitive to aqueous halide ions at physiological concentrations. J. Heterocycl. Chem. 36, 949-951.

Gilbert, D. F., Wilson, J. C., Nink, V., Lynch, J. W., and Osborne, G. W. (2009). Multiplexed labeling of viable cells for high-throughput analysis of glycine receptor function using flow cytometry. Cytometry 75A, 440-449.

Gorostiza, P, and Isacoff, E. Y. (2008). Optical switches for remote and noninvasive control of cell signaling. Science 322, 395-359.

Hara, M., Inoue, M., Yasukura, T., Ohnishi, S., and Inagaki, C. (1993). Spatial diversity of chloride transporters in hippocampal neurons. Ann. N. Y. Acad. Sci. 707, 421-423.

Hara, M., Inoue, M., Yasukura, T., Ohnishi, S., Mikami, Y., and Inagaki, C. (1992). Uneven distribution of intracellular $\mathrm{Cl}^{-}$in rat hippocampal neurons. Neurosci. Lett. 143, 135-135.

Heim, R. (1999). Green fluorescent protein forms for energy transfer. Meth. Enzymol. 302, 408-423.

Heron, S. E., Scheffer, I. E., Berkovic, S. F., Dibbens, L. M., and Mulley, J. C. (2007). Channelopathies in idiopathic epilepsy. Neurotherapeutics 4, 295-304.

Hille, C., Lahn, M.,Lohmannsroben, H. G., and Dosche, C. (2009). Two-photon fluorescence lifetime imaging of intracellular chloride in cockroach salivary glands. Photochem. Photobiol. Sci. 8, 319-327.

Ianowski, J. P., Christensen, R. J., and O’Donnell, M. J. (2002). Intracellular ion activities in Malpighian tubule cells of Rhodnius prolixus: evaluation of $\mathrm{Na}^{+}-\mathrm{K}^{+}-2 \mathrm{Cl}^{-}$cotransport across the basolateral membrane. J. Exp. Biol. 205, 1645-1655.

Illsley, N. P., and Verkman, A. S. (1987). Membrane chloride transport measured using a chloride-sensitive fluorescent probe. Biochemistry 26, 1215-1219.

Inglefield, J.R., and Schwartz-Bloom, R. D. (1997). Confocal imaging of intracellular chloride in living brain slices: measurement of GABAA receptor activity. J. Neurosci. Methods 75, 127-135.

Jares-Erijman, E. A., and Jovin, T. M. (2003). FRET imaging. Nat. Biotechnol. 21, 1387-1395.

Jayaraman, S., Biwersi, J., andVerkman, A. S. (1999). Synthesis and characterization of dual-wavelength $\mathrm{Cl}^{-}$-sensitive fluorescent indicators for ratio imaging. Am. J. Physiol. 276, C747-C757.

Jayaraman, S., Haggie, P., Wachter, R. M., Remington, S. J., and Verkman A. S (2000). Mechanism and cellular applications of a green fluorescent proteinbased halide sensor.J. Biol. Chem. 275, 6047-6050.

Jayaraman, S., and Verkman, A. S. (2000). Quenching mechanism of quinolinium-type chloride-sensitive fluorescent indicators. Biophys. Chem. $85,49-57$. 
Jentsch, T. J. (2008). CLC chloride channels and transporters: from genes to protein structure, pathology and physiology. Crit. Rev. Biochem. Mol. Biol. 43, 3-36.

Jose, M., Nair, D. K., Reissner, C., Hartig, R., and Zuschratter, W. (2007). Photophysics of Clomeleon by FLIM: discriminating excited state reactions along neuronal development. Biophys. J. 92, 2237-2254.

Kennedy, H. J., and Thomas, R. C. (1995). Intracellular calcium and its sodiumindependent regulation in voltageclamped snail neurones. J. Physiol. 484, 533-548.

Kere, J., Lohi, H., and Hoglund, P. (1999). Genetic disorders of membrane transport III. Congenital chloride diarrhea. Am. J. Physiol. 276, G7-G13.

Kerem,B., Rommens,J.M.,Buchanan, J. A., Markiewicz, D., Cox, T. K., Chakravarti, A., Buchwald, M., and Tsui, L. C. (1989). Identification of the cystic fibrosis gene: genetic analysis. Science 245, 1073-1080.

Keynes, R. D. (1963). Chloride in the squid giant axon. J. Physiol. 169, 690-705.

Khirug, S., Yamada, J., Afzalov, R., Voipio, J., Khiroug, L., and Kaila, K. (2008). GABAergic depolarization of the axon initial segment in cortical principal neurons is caused by the $\mathrm{Na}-\mathrm{K}-2 \mathrm{Cl}$ cotransporter NKCC1. J. Neurosci. 28, 4635-4639.

Kitano, I., Mori, N., and Matsunaga, T. (1995). Role of endolymphatic anion transport in forskolin-induced $\mathrm{Cl}^{-}$ activity increase of scala media. Hear. Res. 83, 37-42.

Kneen, M., Farinas, J., Li, Y., and Verkman, A. S. (1998). Green fluorescent protein as a noninvasive intracellular pH indicator. Biophys. J. 74, 1591-1599.

Koch, M. C., Steinmeyer, K., Lorenz, C., Ricker, K., Wolf, F., Otto, M., Zoll, B., Lehmann-Horn, F., Grzeschik, K. H., and Jentsch, T. J. (1992). The skeletal muscle chloride channel in dominant and recessive human myotonia. Science 257, 797-800.

Krapf, R., Berry, C. A., and Verkman, A. S. (1988a). Estimation of intracellular chloride activity in isolated perfused rabbit proximal convoluted tubules using a fluorescent indicator. Biophys. J. 53, 955-962.

Krapf, R., Illsley, N. P., Tsang, H. C., and Verkman, A. S. (1988b). Structureactivity relationships of chloridesensitive fluorescent indicators for biological application. Anal. Biochem. 169, 142-150.

Kruger, W., Gilbert, D., Hawthorne, R., Hryciw, D., Frings, S., Poronnik, Ph., and Lynch, J. W. (2005). A yellow fluorescent protein-based assay for high- throughput screening of a glycine and $\mathrm{GABA}_{\mathrm{A}}$ receptor chloride channels. Neurosci. Lett. 380, 340-345.

Kuner, T., and Augustine, G. J. (2000). A genetically encoded ratiometric indicator for chloride: capturing chloride transients in cultured hippocampal neurons. Neuron 27, 447-459.

La Cour,M., Baekgaard,A., and Zeuthen, T. (1997). Antibodies against a furosemide binding protein from Ehrlich ascites tumour cells inhibit $\mathrm{Na}^{+}, \mathrm{K}^{+}, \mathrm{Cl}^{-}$ co-transport in frog retinal pigment epithelium. Acta Ophthalmol. Scand. 75, 405-408.

Ladle, R. O., and Walker, J. L. (1975). Intracellular chloride activity in frog heart. J. Physiol. 251, 549-559.

Lau, K. R., Evans, R. L., and Case, R. M. (1994). Intracellular $\mathrm{Cl}^{-}$concentration in striated intralobular ducts from rabbit mandibular salivary glands. Pflugers Arch. 427, 24-32.

Lauf, P. K., and Adragna, N. C. (2004). Twenty-five years of $\mathrm{K}-\mathrm{Cl}$ cotransport: from stimulation by a thiol reaction to cloning of the full-length KCCs. $A d v$. Exp. Med. Biol. 559, 11-28.

Lerche, H., Weber, Y. G., Jurkat-Rott, K., and Lehmann-Horn, F. (2005). Ion channel defects in idiopathic epilepsies. Curr. Pharm. Des. 11, 2737-2752.

Llopis, J., McCaffery, J. M., Miyawaki, A., Farquhar, M. G., and Tsien, R. Y. (1998). Measurements of cytosolic, mitochondrial, and Golgi $\mathrm{pH}$ in single living cells with green fluorescent proteins. Proc. Natl. Acad. Sci. U.S.A. 95, 6803-6808.

Lloyd, S. E., Pearce, S. H., Fisher, S. E., Steinmeyer, K., Schwappach, B., Scheinman, S. J., Harding, B., Bolino, A., Devoto, M., and Goodyer, P. (1996). A common molecular basis for three inherited kidney stone diseases. Nature 379, 445-449.

Lorenzen, I., Aberie, T., and Plieth, C. (2004). Salt stress-induced chloride flux: a study using transgenic Arabidopsis expressing a fluorescent anion probe. Plant J. 38, 539-544.

Ma, T., Thiagarajah, J. R., Yang, H., Sonawane N. D., Folli, C., Galietta, L. J. V., and Verkman, A.S. (2002a). Thiazolidinone CFTR inhibitor identified by high-throughput screening blocks cholera toxininduced intestinal fluid secretion. J. Clin. Invest. 110, 1651-1658.

Ma, T., Vetrivel, L., Yang, H., Pedemonte, N., Zegarra-Moran, O., Galietta, L. J. V., and Verkman A. S. (2002b). Highaffinity activators of cystic fibrosis transmembrane conductance regulator (CFTR) chloride conductance identified by high-throughput screening. J. Biol. Chem. 277, 37235-37241.
Macdonald, R. L., Gallagher, M. J., Feng, H. J., and Kang, J. (2004). $\mathrm{GABA}(\mathrm{A})$ receptor epilepsy mutations. Biochem. Pharmacol. 68, 1497-1506.

Mannuzzu, L. M., Moronne, M. M., and Isacoff, E. Y. (1996). Direct physica measure of conformational rearrangement underlying potassium channel gating. Science 271, 213-216.

Mansoura,M.K.,Biwersi.J.,Ashlock,M.A. and Verkman, A.S. (1999). Fluorescent chloride indicators to assess the efficacy of CFTR cDNA delivery. Hum. Gene Ther. 10, 861-875.

Marandi, N., Konnerth, A., and Garaschuk, O. (2002). Two-photon chloride imaging in neurons of brain slices. Pflugers Arch. 445, 357-365.

Markova, O., Mukhtarov, M., Real, E., Jacob, Y., and Bregestovski, P. (2008). Genetically encoded chloride indicator with improved sensitivity. J. Neurosci. Methods 170, 67-76.

Matsuda, T., and Cepko, C. L. (2004). Electroporation and RNA interference in the rodent retina in vivo and in vitro. Proc. Natl. Acad. Sci. U.S.A. 101, 16-22.

Mauro,A. (1954). Electrochemical potential difference of chloride ion in the squid giant axon-sea water system. Fed. Proc. 13, 96.

Metzger, F., Repunte-Canonigo, V., Matsushita, S., Akemann, W., DiezGarcia, J., Ho, C. S., Iwasato, T., Grandes, P., Itohara, S., Joho, R. H., and Knopfel, T. (2002). Transgenic mice expressing a $\mathrm{pH}$ and $\mathrm{Cl}^{-}$sensing yellow-fluorescent protein under the control of a potassium channel promoter. Eur. J. Neurosci. 15, 40-50.

Miesenbock, G., De Angelis, D., and Rothman, J. E. (1998). Visualizing secretion and synaptic transmission with $\mathrm{pH}$-sensitive green fluorescent proteins. Nature 394, 192-195.

Miyawaki, A., Griesbeck, O., Heim, R. and Tsien, R. Y. (1999). Dynamic and quantitative $\mathrm{Ca}^{2+}$ measurements using improved cameleons. Proc. Natl. Acad. Sci. U.S.A. 96, 2135-2140.

Miyawaki, A., Llopis, J., Heim, R., McCaffery, J. M., Adams, J. A., Ikura, M., and Tsien, R. Y. (1997). Fluorescent indicators for $\mathrm{Ca}^{2+}$ based on green fluorescent proteins and calmodulin. Nature 388, 882-887.

Miyazaki,H., Shiozaki, A., Niisato, N., and Marunaka, Y. (2007). Physiological significance of hypotonicity-induced regulatory volume decrease: reduction in intracellular $\mathrm{Cl}^{-}$concentration acting as an intracellular signaling. Am. J. Physiol. Renal Physiol. 292, F1411-F1417.

Miyazaki, H., Shiozaki, A., Niisato, N., Ohsawa, R., Itoi, H., Ueda, Y., Otsuji, E.,
Yamagishi, H., Iwasaki, Y., Nakano, T., Nakahari, T., and Marunaka,Y. (2008). Chloride ions control the G1/S cellcycle checkpoint by regulating the expression of p21 through a p53independent pathway in human gastric cancer cells. Biochem. Biophys. Res. Commun. 366, 506-512.

Muanprasat, C., Kaewmokul, S., and Chatsudthipong, V. (2007). Identification of new small molecule inhibitors of cystic fibrosis transmembrane conductance regulator protein: in vitro and in vivo studies. Biol. Pharm. Bull. 30, 502-507.

Muanprasat, C., Sonawane, N. D., Salinas, D., Taddei,A., Galietta, L. J.V., and Verkman, A. S. (2004). Discovery of glycine hydrazide pore-occluding cftr inhibitors: mechanism, structureactivity analysis, and in vivo efficacy. J. Gen. Physiol. 124, 125-137.

Mukhtarov, M., Markova, O., Real, E., Jacob, Y., Buldakova, S., and Bregestovski, P. (2008). Monitoring of chloride and activity of glycine receptor channels using genetically encoded fluorescent sensors. Philos. Trans. $R$. Soc. A. 366, 3445-3462.

Munkonge, F., Alton, E. W., Andersson, C., Davidson,H.,Dragomir,A.,Edelman, A., Farley, R., Hjelte, L., McLachlan, G., Stern, M., and Roomans, G. (2004). Measurement of halide efflux from cultured and primary airway epithelial cells using fluorescence indicators. Cyst. Fibros. 3(Suppl. 2), 171-176.

Nakamura, T., Kaneko, H., and Nishida, N. (1997). Direct measurement of the chloride concentration in newt olfactory receptors with the fluorescent probe. Neurosci. Lett. 237, 5-8.

Neild, T.O., and Thomas, R.C. (1973). New design for a chloride-sensitive microelectrode. J. Physiol. 231, 7P-8P.

Neild, T. O., and Thomas, R. C. (1974). Intracellular chloride activity and the effects of acetylcholine in snail neurones. J. Physiol. 242, 453-470.

Ormo, M., Cubitt, A. B., Kallio, K., Gross, L. A., Tsien, R. Y., and Remington, S. J. (1996). Crystal structure of the Aequorea victoria green fluorescent protein. Science 273, 1392-1395.

Painter, R. G., and Wang, G. (2006). Direct measurement of free chloride concentration in the phagolysosomes of human neutrophils. Anal. Chem. 78, 3133-3137.

Pedemonte, N., Lukacs, G. L., Du, K., Caci, E., Zegarra-Moran, O., Galietta, L. J. V., and Verkman A.S. (2005a). Small-molecule correctors of defective $\Delta$ F508-CFTR cellular processing identified by highthroughput screening. J. Clin. Invest. $115,2564-2571$ 
Pedemonte, N., Sonawane, N. D., Taddei, A., Hu, J., Zegarra-Moran, O., Suen, Y. F., Robins, L. I., Dicus, C. W., Willenbring, D., Nantz, M. H., Kurth, M. J., Galietta, L. J. V., and Verkman,A.S. (2005b). Phenylglycine and sulfonamide correctors of defective $\Delta \mathrm{F} 508$ and G551D cystic fibrosis transmembrane conductance regulator chloride-channel gating. Mol. Pharmacol. 67, 1797-1807.

Pless, S. A., and Lynch, J. W. (2008). Illuminating the structure and function of Cys-loop receptors. Clin. Exp. Pharmacol. Physiol. 35, 1137-1142.

Pless, S.A., and Lynch,J.W. (2009). Distinct conformational changes in activated agonist-bound and agonist-free glycine receptor subunits. J. Neurochem. 108, 1585-1594.

Pollok, B. A., and Heim, R. (1999). Using GFP in FRET-based applications. Trends Cell Biol. 9, 57-60.

Pond, B. B., Berglund, K., Kuner, T., Feng, G., Augustine, G. J., and Schwartz-Bloom, R. D. (2006). The chloride transporter $\mathrm{Na}^{+}-\mathrm{K}^{+}-\mathrm{Cl}^{-}$ cotransporter isoform- 1 contributes to intracellular chloride Increases after in vitro ischemia. J. Neurosci. 26, 1396-1406.

Rhoden, K., Cianchetta, S., Duchi, S., and Romeo, G. (2008). Fluorescence quantitation of thyrocyte iodide accumulation with the yellow fluorescent protein variant YFP-H148Q/I152L. Anal. Biochem. 373, 239-246.

Rhoden, K. J., Cianchetta, S., Stivani, V., Portulano, C., Galietta, L. J. V., and Romeo, G. (2007).Cell-based imaging of sodium iodide symporter activity with the yellow fluorescent protein variant YFP-H148Q/I152L. Am. J. Physiol. Cell Physiol. 292, 814-823.

Rohrbough, J., and Spitzer, N. C. (1996). Regulation of intracellular $\mathrm{Cl}^{-}$levels by $\mathrm{Na}(+)$-dependent $\mathrm{Cl}^{-}$cotransport distinguishes depolarizing from hyperpolarizing GABAA receptormediated responses in spinal neurons. J. Neurosci. 16, 82-91.

Russell,J.M. (2000). Sodium-potassiumchloride cotransport. Physiol. Rev. 80, 211-276.

Sah, R., and Schwartz-Bloom, R.D. (1999). Optical imaging reveals elevated intracellular chloride in hippocampal pyramidal neurons after oxidative stress. J. Neurosci. 19, 9209-9217.

Sato,M.,Austin, G., Yai, H., and Maruhashi, J. (1968). The ionic permeability changes during acetylcholine-induced responses of Aplysia ganglion cells. J. Gen. Physiol. 51, 321-345.

Satoh, H., Kaneda, M., and Kaneko, A. (2001). Intracellular chloride concentration is higher in rod bipolar cells than in cone bipolar cells of the mouse retina. Neurosci. Lett. 310, 161-164.

Schwartz, R. D., and Yu, X. (1995). Optical imaging of intracellular chloride in living brain slices. J. Neurosci. Methods $62,185-192$.

Schwiening, C. J., and Thomas, R. C. (1996). Relationship between intracellular calcium and its muffling measured by calcium iontophoresis in snail neurones. J. Physiol. 491, 621-633.

Sekar, R. B., and Periasamy, A. (2003). Fluorescence resonance energy transfer (FRET) microscopy imaging of live cell protein localizations. J. Cell Biol. $160,629-633$.

Servetnyk,Z., and Roomans, G. M. (2007). Chloride transport in NCL-SG3 sweat gland cells: channels involved. Exp. Mol. Pathol. 83, 47-53.

Shiang, R., Ryan, S. G., Zhu, Y. Z., Hahn, A. F., O'Connell, P., and Wasmuth, J. J. (1993). Mutations in the alpha 1 subunit of the inhibitory glycine receptor cause the dominant neurologic disorder, hyperekplexia. Nat. Genet. 5, 351-358.

Simon, D. B., and Lifton, R. P. (1996) The molecular basis of inherited hypokalemic alkalosis: Bartter's and Gitelman's syndromes. Am. J. Physiol. 271, F961-F966.

Slemmer,J.,Matsuchita, S.,DeZeeuw, C. I., Weber, J. T., and Knopfel, T. (2004). Glutamate-induced elevations in intracellular chloride concentration in hippocampal cell cultures derived from EFYP-expressing mice. Eur. J. Neurosci. 19, 2915-2922.

Strickholm, A., and Wallin, B. G. (1965). Intracellular chloride activity of crayfish giant axons. Nature 208, 790-791.

Thomas, R. C. (1977). The role of bicarbonate, chloride and sodium ions in the regulation of intracellular $\mathrm{pH}$ in snail neurones. J. Physiol. 273, 317-338.

Thomas, R. C. (1978). Ion-Sensitive Intracellular Microelectrodes. London, Academic Press.

Thoreson, W. B., and Bryson, E. J. (2004). Chloride equilibrium potential in salamander cones. BMC Neurosci. 5, 53.

Tsien, R. Y. (1998). The green fluorescent protein. Annu. Rev. Biochem. 67, 509-544.
Tsien, R. Y., Bacskai, B. J., and Adams, S. R. (1993). FRET for studying intracellular signalling. Trends Cell Biol. 3, 242-245.

Tyzio, R., Cossart, R., Khalilov, I. Minlebaev, M., Hubner, C. A., Represa, A., Ben-Ari, Y., and Khazipov, R. (2006).Maternal oxytocin triggers a transient inhibitory switch in GABA signaling in the fetal brain during delivery. Science 314, 1788-1792.

Vaughan-Jones, R. D. (1979). Non-passive chloride distribution in mammalian heart muscle: micro-electrode measurement of the intracellular chloride activity. J. Physiol. 295, 83-109.

Verkman, A. S. (1990). Development and biological applications of chloridesensitive fluorescent indicators. Am. J. Physiol. 259, C375-C388.

Verkman, A. S., and Galietta, L. J. (2009). Chloride channels as drug targets. Nat. Rev. Drug Discov. 8, 153-157.

Verkman, A.S., Sellers, M.C., Chao, A. C., Leung, T., and Ketcham, R. (1989). Synthesis and characterization of improved chloride-sensitive fluorescent indicators for biological applications. Anal. Biochem. 178, 355-361.

Wachter, R. M., Elsliger, M.-A., Kallio, K., Hanson, G., and Remington, S. J. (1998). Structural basis of spectral shifts in the yellow-emission variants of green fluorescent protein. Structure 6, 1267-1277.

Wachter, R. M., and Remington, S. J. (1999). Sensitivity of the yellow variant of green fluorescent protein to halides and nitrate. Curr. Biol. 9, R628-R629.

Wachter, R. M., Yarbrough, D., Kallio, K., and Remington, S. J. (2000). Crystallographic and energetic analysis of binding of selected anions to the yellow variants of green fluorescent protein. J. Mol. Biol. 301, 157-171.

Walker, J. L. (1971). Ion-specific liquid ion exchanger micro-electrodes. Analyt. Chem. 43, 89A-93A.

Walker, J. L., and Brown, A. M. (1970). Unified account of the variable effects of carbon dioxide on nerve cells Science 167, 1502-1504.

Walker, J. L., and Brown, H. M. (1977) Intracellular ionic activity measurements in nerve and muscle. Physiol. Rev. 57, 729-778.

Wallrabe, H., and Periasamy, A. (2005) Imaging protein molecules using FRET and FLIM microscopy. Curr. Opin. Biotechnol. 16, 19-27.

Wolfbeis, O. S., and Urbano, E. (1983) Fluorimetric method for analysis of chloride, bromide and iodide. Fresenius J. Anal. Chem. 314, 577-581.

Woll, E., Gschwentner, M., Furst, J., Hofer, S., Buemberger, G., Jungwirth, A., Frick, J., Deetjen, P., and Paulmichl, M. (1996). Fluorescenceoptical measurements of chloride movements in cells using the membrane-permeable dye diH-MEQ. Pflugers Arch. 432, 486-493.

Xu, L. N., Na, W. L., Liu, X., Hou, S. G., Lin, S., Yang, H., and Ma, T. H. (2008). Identification of natural cumarine compounds that rescue defective DeltaF508-CFTR chloride channel gating. Clin. Exp. Pharmacol. Physiol. 35, 878-883.

Yang, H., Shelat, A. A., Guy, R. K., Gopinath, V.S., Ma, T., Du, K., Lukacs, G. L., Taddei, A., Folli, C., Pedemonte, N., Galietta, L. J. V., and Verkman, A. S. (2003). Nanomolar affinity small molecule correctors of defective $\Delta$ F508-CFTR chloride channel gating. J. Biol. Chem. 278, 35079-35085.

Zaccolo, M., and Pozzan, T. (2000). Imaging signal transduction in living cells with GFP-based probes. IUBMB Life 49, 375-379.

Zhang, L. L., Pathak, H. R., Coulter, D. A., Freed, M. A., and Vardi, N. (2006) Shift of intracellular chloride concentration in ganglion and amacrine cells of developing mouse retina. J. Neurophysiol. 95, 2404-2416.

Conflict of Interest Statement: The authors declare that the research was conducted in the absence of any commercial or financial relationships that could be construed as a potential conflict of interest.

Received: 16 July 2009; paperpending published: 03 August 2009; accepted: 28 August 2009; published online: 04 December 2009.

Citation: Bregestovski P, Waseem T and Mukhtarov M (2009) Genetically encoded optical sensors for monitoring of intracellular chloride and chloride-selective channel activity. Front. Mol. Neurosci. 2:15. doi: 10.3389/neuro.02.015.2009

Copyright (C) 2009 Bregestovski, Waseem and Mukhtarov. This is an open-access article subject to an exclusive license agreement between the authors and the Frontiers Research Foundation, which permits unrestricted use, distribution, and reproduction in any medium, provided the original authors and source are credited. 